\title{
DIGITALCOMMONS
}

$1-1-1982$

\section{Constitutional Protection of Commercial Speech}

Jonathan Weinberg

Wayne State University, weinberg@wayne.edu

\section{Recommended Citation}

Jonathan Weinberg, Constitutional Protection of Commercial Speech, 82 Colum. L. Rev. 720 (1982).

Available at: http://digitalcommons.wayne.edu/lawfrp/39

This Article is brought to you for free and open access by the Law School at DigitalCommons@WayneState. It has been accepted for inclusion in Law Faculty Research Publications by an authorized administrator of DigitalCommons@WayneState. 


\section{NOTES}

\section{Constitutional Protection of Commercial Speech}

Over the course of the past seven years, the Supreme Court has abandoned a legal regime affording no first amendment ${ }^{1}$ protection to commercial speech; ${ }^{2}$ flirted with a standard under which, arguably, all true, nonmisleading commercial speech that did not relate to illegal activity was fully protected; ${ }^{3}$ and settled on a purportedly definitive rule granting commercial speech a lesser, limited measure of protection 4 commensurate with its "subordinate position" 5 among classes of protected speech. The difficulty with the Court's analysis, however, is that at no point during its legal wanderings has it ever articulated sturdy rationales to support its holdings. Instead, it has seemed to decide each case on its facts, deciding first the desired results and manipulating-or creating-doctrine to fit. ${ }^{6}$ In its most important recent

1. "Congress shall make no law . . . abridging the freedom of speech, or of the press . . .." U.S. Const. amend. I.

2. Valentine v. Chrestensen, 316 U.S. 52 (1942); see also Breard v. Alexandria, 341 U.S. 622 (1951). The initial problem presented in dealing with commercial speech is that of definition. Two ingredients must at a minimum be present. The first is one of content: the speech must tend to promote the purchasing of goods or services. The second is one of motivation: the purpose of the speech must be the advancement of the financial interests of the speaker via that transaction.

Economic motivation alone can never be sufficient to classify speech as commercial. Newspapers, professional authors, and paid public speakers all have at least partly economic motivation in disseminating their speech, yet that, without more, does not make that speech in any way commercial. New York Times Co. v. Sullivan, 376 U.S. 254, 265-66 (1964). This point is still occasionally missed. See, e.g., Carey v. Population Serv. Int'l, Inc., 431 U.S. 678, 716-17 (1977) (Stevens, J., concurring) (characterizing "the business of exhibiting [sexually explicit] motion pictures for profit" as commercial speech). Similarly, commercial content alone is insufficientConsumer Reports is not in the same category, for first amendment purposes, as product advertising. Hence, it is the combination of the two elements that is the key.

For commercial speech analysis to come into play at all, the good or service, such as religious material or books, cannot itself be independently protected by the first amendment. See Heffron v. International Soc'y for Krishna Consciousness, 452 U.S. 640 (1981) (religious material); Breard v. Alexandria, 341 U.S. 622, 690 (1951) (Black, J., dissenting) (magazine subscriptions). For an extensive analysis of the problem of defining commercial speech, see Comment, First Amendment Protection for Commercial Advertising: The New Constitutional Doctrine, 44 U. Chi. L. Rev. 205, 222-36 (1976).

3. See Linmark Assocs. v. Township of Willingboro, 431 U.S. 85 (1977); Virginia State Bd. of Pharmacy v. Virginia Citizens Consumer Council, Inc., 425 U.S. 748, 769-73 (1976).

4. Central Hudson Gas \& Elec. Corp. v. Public Serv. Comm'n, 447 U.S. 557 (1980).

5. Id. at 589 (Rehnquist, J., dissenting) (quoting Ohralik v. Ohio State Bar Ass'n, 436 U.S. $447,455-56(1978))$.

6. See Cox, The Supreme Court, 1979 Term-Foreword: Freedom of Expression in the Burger Court, 94 Harv. L. Rev. 1, 26 (1980). See generally Wechsler, Toward Neutral Principles of Constitutional Law, 73 Harv. L. Rev. 1, 10-20 (1959) (emphasizing the importance of reasoning and analysis that transcend immediate results).

One particularly troubling branch of the law in this area is federal and state regulation of cigarette and liquor advertising. See Cox, supra, at 34. The Federal Cigarette Labeling and Advertising Act, 15 U.S.C. $\S \S 1331-1340$ (1976) (forbidding broadcast advertising of cigarettes), is put into question by current commercial speech doctrine. The Court has rationalized the cigarette ban by noting "the special problems of advertising on the electronic broadcast media," Bates v. State Bar of Arizona, 433 U.S. 350, 384 (1977), but the original case upholding that prohibition, prior to the expansion of protection for commercial speech, made no such distinction. Capital Broadcasting Co. v. Mitchell, 333 F. Supp. 582 (D.D.C. 1971), aff'd mem. sub nom. Capital Broadcasting Co. v. Acting Attorney General, 405 U.S. 1000 (1972); see infra text 
pronouncement, Central Hudson Gas \& Electric Corp. v. Public Service Commission, ${ }^{7}$ the Court neglected to supply any rationale at all to buttress its holding - a factor that makes the durability of that holding questionable ${ }^{8}$ and that has contributed to a wide divergence of opinion among commentators as to the degree of constitutional protection that commercial speech should receive. ${ }^{9}$

This Note attempts to articulate a principled ground for protection of commercial speech, and to consider what the scope of that protection might be. Initially, the Note traces the history of the commercial speech doctrine in the Supreme Court. The Note then outlines a framework of values and interests: the values determine what kinds of speech are to be protected, and the interests determine the scope of permissible restrictions on that speech. Applying this framework to the question of commercial speech, the Note concludes that commercial speech may be subject to specific types of regulation-such as restriction of redundant speakers-that could not constitutionally be applied in other areas of speech. Any restrictions, however, placed upon the dissemination of true and nonmisleading commercial speech, for fear that its recipients will act on the information provided, should be subject to the same strict scrutiny such restrictions are given elsewhere in first amendment jurisprudence. ${ }^{10}$

accompanying notes 186-90. State statutes banning liquor advertising, e.g., Fla. Stat. Ann. § 561.42(10)-(12) (West 1979); Mass. Gen. Laws Ann. ch. 138, \& 24 (West 1974); Utah Code Ann. $\$ \S 32-7-26$ to -28 (1953 \& Supp. 1981), may present similar difficulties for the Court. The Oklahoma ban on liquor advertising was recently struck down as violative of first amendment guarantees protecting.commercial speech. Oklahoma Telecasters Ass'n v. Crisp, No. Civ-81-439W, slip op. (W.D. Okla. Feb. 10, 1982) (available Apr. 26, 1982, on LEXIS, Genfed library, Dist file).

7. 447 U.S. 557 (1980).

8. A number of lower courts have strongly indicated their uncertainty in the commercial speech area. See, e.g., In re R.M.J., 609 S.W.2d 411, 412 (Mo. 1980) ("We are urged now by respondent to follow the Central Hudson model. We respectfully decline to enter the thicket of attempting to anticipate and to satisfy the subjective ad hoc judgments of a majority of the United States Supreme Court.") (emphasis in original), rev'd, 102 S. Ct. 929 (1982).

9. Compare The Supreme Court, 1979 Term, 94 Harv. L. Rev. 1, 164 (1980) ("Because commercial expression furthers the same values and interests that require protection of other forms of speech, regulation based on the content of the former should receive full constitutional protection"), with Jackson \& Jeffries, Commercial Speech: Economic Due Process and the First Amendment, 65 Va. L. Rev. 1, 14 (1979) ("Measured in terms of traditional First Amendment principles, commercial speech is remarkable for its insignificance.").

10. The Note discusses the constitutional protection of true, nonmisleading commercial speech only. The Supreme Court has generally allowed close regulation of false and misleading commercial speech on the ground that commercial speech is more durable and more easily verifiable by its disseminator than other speech. See Central Hudson, 447 U.S. at 564 n.6; Virginia State Bd. of Pharmacy v. Virginia Citizens Consumer Council, Inc., 425 U.S. 748, 771-72 \& n.24 (1976); id. at 777-81 (Stewart, J., concurring); Friedman v. Rogers, 440 U.S. 1, 10 (1979). But see Bates v. State Bar of Arizona, 433 U.S. 350, 397 (1977) (Powell, J., dissenting in relevant part); Illinois Ass'n of Realtors v. Village of Bellwood, 516 F. Supp. 1067, 1074 n.8 (N.D. Ill. 1981); Farber, Commercial Speech and First Amendment Theory, 74 Nw. U.L. Rev. 372, 384-86 (1979).

The Court has used this rationale to justify a degree of regulation of commercial speech that would be "utterly intolerable" were it to be applied to political speech. Cox, supra note 4, at 32; see infra note 91 . The content-based nature of regulation of misleading speech and the necessity, if regulation is to be effective, of broad prophylactic rules that will screen out some protectable speech along with the unprotectable, make the area of misleading speech one of continuing difficulty and confusion. 


\section{History of Commercial Speech Doctrine}

The Supreme Court's first efforts to protect commercial speech were tentative; initially, the Court employed a balancing test, determining whether the speech contained material of sufficient public interest that the benefits of free circulation outweighed the state's police power interest in suppression. ${ }^{11}$ Its holdings soon became more firm, before long establishing what appeared to be a solid rule that truthful and nonmisleading commercial speech was entitled to undiluted first amendment protection. ${ }^{12}$ By 1979 the Court had begun to retreat from that position ${ }^{13}$ until, in Central Hudson Gas \& Electric Corp. v. Public Service Commission, ${ }^{14}$ it declared that restrictions designed to keep true commercial information from the public were legitimate in appropriate circumstances. Central Hudson promulgated a rule under which courts could treat such restrictions indistinguishably from simple "time, place, and manner" regulations, applying a relatively relaxed intermediate standard of review. In addition, however, the rule provided that courts should subject the restrictions to a potentially strict "least restrictive means" test as well, thus ensuring judicial control over individual cases. Though this analysis recognizes the likelihood that countervailing public interests will often collide with first amendment interests, it marks a shift to what may well, in future cases, become wholly unprincipled adjudication.

\section{A. From Chrestensen to Bigelow: The Shift from Motivation to Content}

Traditional first amendment jurisprudence held commercial speech to be wholly unworthy of protection. The Court first considered the problem in the 1942 case of Valentine $v$. Chrestensen, ${ }^{15}$ rejecting a first amendment challenge to a city ordinance prohibiting the distribution of "commercial .... [or] business advertising matter" in the streets. ${ }^{16}$ The Court made it plain that advertising, to be defined by looking at the motivation of the speaker, ${ }^{17}$ was to be treated as the "pursu[ance of] gainful occupation" 18 only, and not as

11. Bigelow v. Virginia, 421 U.S. 809 (1975).

12. See Linmark Assocs. v. Township of Willingboro, 431 U.S. 85 (1977); Virginia State Bd. of Pharmacy v. Virginia Citizens Consumer Council, Inc., 425 U.S. 748 (1976); infra text accompanying notes 31-56.

13. See Friedman v. Rogers, 440 U.S. 1 (1979) (broad definition of misleading speech and suggestion, id. at 13 , that even nonmisleading commercial speech is entitled to lesser protection); Ohralik v. Ohio State Bar Ass'n, 436 U.S. 447, 456 (1978) (commercial speech entitled to only "limited measure of protection, commensurate with its subordinate position in the scale of First Amendment values").

14. 447 U.S. 557 (1980).

15. 316 U.S. 52 (1942).

16. Id. at 53 n.1.

17. The Court found it of little note that Chrestensen, who was distributing handbills soliciting visitors for the Navy submarine he exhibited, attached to his handbill a protest against the action of the local authorities in refusing him public wharfage facilities. It dismissed arguments based on the partly political content of the handbill, and focused on what it saw to be the plain motivation behind it. Id. at 55. See generally Schiro, Commercial Speech: The Demise of a Chimera, 1976 Sup. Ct. Rev. 45, 47-48; L. Tribe, American Constitutional Law 652 (1978) ("dominant motive" test for commercial speech).

18. 316 U.S. at 54. 
speech at all. Nine years later, in Breard $\nu$. Alexandria, ${ }^{19}$ the Court rejected a challenge to an ordinance prohibiting commercial door-to-door selling, as applied to a magazine subscription organization. The question, as the Justices saw it, was whether freedom of the press gave magazines unique protection. Justice Reed, writing for the Court, and Justice Black, dissenting, agreed that "[o]f course," a seller of mere "gadgets or brushes" or "pots" could under no circumstances claim first amendment protection. ${ }^{20}$ Again, the Court focused on the motivation of the advertiser rather than the content of his speech, allowing it to ignore the protected nature of the magazines he wished to sell. ${ }^{21}$

This treatment of commercial speech came under increasing attack in the years to follow, ${ }^{22}$ with the first crack in the theoretical wall appearing almost offhandedly in New York Times Co. v. Sullivan. ${ }^{23}$ The Court found in that case that state libel criteria, as applied to an advertisement placed by a civil rights organization, violated the first amendment. It first had to address the argument that because the New York Times, in running the civil rights appeal, was motivated by purely commercial interests, the advertisement constituted mere commercial speech, beyond the ambit of first amendment protection. ${ }^{24}$ The Court disposed of that argument by looking past the Times's motivation and focusing on the content of the speech..$^{25}$ This content test assumed prime importance in the 1975 case of Bigelow v. Virginia. ${ }^{26}$ There, the Court held that where commercial speech contained "factual material of clear 'public interest," " ${ }^{27}$ the state's ability to suppress it would turn on a weighing of the first amendment interest served by the dissemination of the speech against the

19. 341 U.S. 622 (1951).

20. Id. at $641,650 \mathrm{n.*}$. Chief Justice Vinson, dissenting, did not reach the issue.

21. See Schiro, supra note 17, at 54-60; cf. Murdock v. Pennsylvania, 319 U.S. 105 (1943) (upholding first amendment right of Jehovah's Witnesses to sell religious materials door to door).

22. Justice Douglas in a 1959 concurring opinion characterized the Chrestensen holding as "casual, almost offhand . . . [and one which] has not survived reflection," Cammarano v. United States, 358 U.S. 498, 514 (1959) (Douglas, J., concurring), and later referred to it as "illconceived"' and ripe for overruling. Dun \& Bradstreet, Inc. v. Grove, 404 U.S. 898, 904-06 (1971) (Douglas, J., dissenting from denial of cert.). By 1974 a majority of the members of the Court were on record as questioning the validity of the Chrestensen holding. See Lehman v. City of Shaker Heights, 418 U.S. 298, 314 n.6 (1974) (Brennan, J., dissenting) and cases cited supra.

23. 376 U.S. 254 (1964).

24. Id. at 265 .

25. Id. at 265-66. The Court found that the speech "communicated information, expressed opinion, recited grievances, protested claimed abuses, and sought financial support on behalf of a movement whose existence and objectives are matters of the highest public interest and concern," id. at 266 , and was thus worthy of protection.

26. 421 U.S. 809 (1975).

Bigelow was the managing editor of the Virginia Weekly, a newspaper printed and distributed solely in Virginia. The Weekly ran an advertisement for the Women's Pavilion, a for-profit New York abortion referral service. Both abortions and for-profit medical referral services were then legal in New York, but illegal in Virginia. Bigelow was convicted for violation of a statute making it illegal to "encourage or prompt the procuring of abortion," id. at 812-13.

27. Id. at 822 . The Court reasoned that the abortion information provided by the advertisement, in particular the advertisement's statement that "[a]bortions are now legal in New York" without residency requirements, id., would be valuable not only to readers in need of abortion services, "but also to those with a general curiosity about, or genuine interest in, the subject matter or the law of another State and its development, and to readers seeking reform in Virginia." Id. 
police power interest advanced by the regulation. ${ }^{28}$ The Bigelow balancing approach gave unprecedented protection to commercial speech. ${ }^{29}$ It left, however, a good deal of leeway to the Court in future cases; where it is unclear just how much weight should be put on each side of the scale, a balancing approach can yield almost any desired result. ${ }^{30}$

\section{B. Virginia Board and Full Protection}

In 1976, with Virginia State Board of Pharmacy v. Virginia Citizens Consumer Council, Inc., ${ }^{31}$ the Court moved into a new era, establishing protection for pure commercial speech, that is, speech devoid of any content other than the proposal for a commercial transaction. ${ }^{32}$ A Virginia statute prohibited pharmacists from advertising prices for prescription drugs. ${ }^{33}$ The statute was challenged by prescription drug customers who claimed a first amendment right to receive drug price information that pharmacists wished to communicate to them. Justice Blackmun, writing for the Court, first spoke to the threshold question of whether a restriction on the pharmacists' ability to communicate could infringe a first amendment right of the consumers, and concluded that it could. ${ }^{34} \mathrm{He}$ went on to describe the usefulness to the consumer of the information conveyed by commercial speech. The listener's interest, it was explained, "may be as keen, if not keener by far, than his interest in the day's most urgent political debate." ${ }^{35}$ The legislation in ques-

28. Id. at 826; see Comment, First Amendment Protection for Commercial Speech: An Optical Illusion?, 31 U. Fla. L. Rev. 799, 802 (1979). Justice Rehnquist dissented, in part on the ground that "we have always refused to distinguish for First Amendment purposes on the basis of content," and that the subject matter of the advertisement was therefore irrelevant. The speech was still commercial advertising and as such unprotected. 421 U.S. at 831 .

Content-based criteria, though, were coming into increasing vogue at the Court. Just a year later, the Court decided Young v. American Mini Theatres, Inc., 427 U.S. 50 (1976). In that case a Detroit ordinance restricting the projection of sexually explicit but nonobscene films was upheld, partly on the ground that the content of the films made them worthy of somewhat less first amendment protection. In the course of that opinion, Justice Stevens analogized to commercial speech and commented that " $[t]$ he measure of constitutional protection to be afforded commercial speech will surely be governed largely by the content of the communication." Id. at 68-69.

29. The Bigelow holding was, though, of limited precedential value because the independent constitutional interest of abortion rights was implicated. Thus, Justice Blackmun, writing for the Court, could limit his holding with the statement that "[w]e need not decide in this case the precise extent to which the First Amendment permits regulation of advertising that is related to activities the State may legitimately regulate or even prohibit." 421 U.S. at 825 . This aspect of the case, however, played a relatively minor role in the Court's analysis.

30. See generally L. Tribe, supra note 17, at 584; Emerson, First Amendment Doctrine and the Burger Court, 68 Calif. L. Rev. 422, 440 (1980); Comment, supra note 41, at 804 n.35.

31. 425 U.S. 748 (1976).

32. Id. at $760-61$.

33. Virginia pharmacists are in general heavily regulated by the state. Only licensed pharmacists may dispense prescription drugs. Id. at 750-52.

34. Id. at 756-57. Justice Rehnquist, in his dissent, argued that listeners (asserting their "right to receive") should not be able to strike down restrictions on speakers where the listeners could reasonably go out and get the information themselves. The drug customers, he contended, should have no standing since they, or consumer organizations, could easily get price quotes from the pharmacists via "a phone call or a trip to the corner drugstore." 425 U.S. at 782-83. See infra note 102 .

35. Id. at 763-64. 
tion, Justice Blackmun wrote, hit hardest at the poor, sick, and aged; allowing advertising to them meant "more than a convenience. It could mean the alleviation of physical pain or the enjoyment of basic necessities." ${ }^{36}$ Thus, the Court concluded, the consumer had a first amendment interest in receiving the information. The Court continued by asserting a general societal interest in the dissemination of information as to the availability and price of goods and services in the marketplace. "So long as we preserve a predominantly free enterprise economy," such information is "indispensable" to the private economic decisions that make the economy work. ${ }^{37}$

This analysis, however, appears to reflect interests foreign to those valued in traditional first amendment jurisprudence. Economic efficiency and the economic interests of consumers are important, but are akin to property interests rather than to those related to expression or association. ${ }^{38}$ The mere importance of an economic interest does not as such transform it into a first amendment interest, ${ }^{39}$ and it had not previously been thought that the first amendment constitutionalized classical free-market economic theory. ${ }^{40}$ Thus, it seems that Justice Rehnquist, dissenting, was more true than the majority to historic first amendment concerns in rejecting these arguments as "presumptively ... the concern of the Virginia Legislature, which sits to balance these and other claims in the process of making laws such as the one here under attack." 41

After stating the existence of first amendment interests in commercial communication, ${ }^{42}$ the Court in Virginia Board reiterated the police power

36. Id.

37. Id. at 765. Individual Justices had expressed this idea before. See Dun \& Bradstreet, Inc. v. Grove, 404 U.S. 898, 904-06 (1971) (Douglas, J., dissenting from denial of cert.); FTC v. Proctor \& Gamble Co., 386 U.S. 568, 603 (1967) (Harlan, J., concurring). (1948).

38. See generally A. Meiklejohn, Free Speech and Its Relation to Self-Government 37-39

39. See Virginia Board, 425 U.S. at 787 (Rehnquist, J., dissenting) ("It is undoubtedly arguable that many people in this country regard the choice of shampoo as just as important as who may be elected to local, state, or national political office, but that does not automatically bring information about competing shampoos within the protection of the First Amendment.").

40. Justice Rehnquist, arguing that "there is certainly nothing in the . . Constitution which requires the Virginia Legislature to hew to the teachings of Adam Smith in its legislative decisions," 425 U.S. at 784 (dissenting opinion), consciously echoed Justice Holmes's dissent in Lochner v. New York, 198 U.S. 45, 75 (1915) ("The Fourteenth Amendment does not enact Mr. Herbert Spencer's Social Statics.").

Justice Rehnquist's accusation that the Court was reviving the doctrine of Lochner has been supported by a number of commentators. See, e.g., Jackson \& Jeffries, supra note 9, at 30-31; Comment, supra note 28 , at 812 .

41. 425 U.S. at 783 (Rehnquist, J., dissenting).

42. The Court also hesitantly suggested that advertising might be considered political speech, on the ground that it is important for the formation of opinions about economic regulation. "[E]ven if the First Amendment were thought to be primarily an instrument to enlighten public decisionmaking in a democracy, we could not say that the free flow of information does not serve that goal." 425 U.S. at 765 (footnotes omitted). For commentators' reactions, compare Jackson \& Jeffries, supra note 9, at 15 ("The typical newspaper advertisement or television commercial makes no comment on governmental personnel or policy. It does not marshall information relevant to political action, nor does it focus public attention on questions of political significance."), and Redish, The First Amendment in the Marketplace: Commercial Speech and the Values of Free Expression, 39 Geo. Wash. L. Rev. 429, 438 (1971) ("It may well be that commercial speech does not, even indirectly, aid the public in the performance of its self- 
interests advanced by the state. ${ }^{43}$ Having reached that point, however, it did not in fact weigh the two sets of interests. Instead, it announced that the first amendment prohibited such balancing, however reasonable or well-intentioned. It laid down a rule that a state simply may not, consistently with the first amendment, completely suppress truthful and nonmisleading advertising of lawful products on the ground that allowing the information to be conveyed to the public would have a harmful effect on them or on the advertisers; ${ }^{44}$ this decision, the Court explained, was one that "the First Amendment makes for us." 45 Such a restriction would be "highly paternalistic" and inconsistent with traditional first amendment principles and with the notion that "people will perceive their own best interests if only they are well enough informed." "46 Thus, even though the Virginia Board Court structured its opinion in a manner suggesting that it would engage in balancing, it actually adopted a per se approach. ${ }^{47}$

Subsequent Court decisions paid lip service to balancing, but recognized that Virginia Board, if taken seriously, granted close to complete first amendment protection to commercial speech. In Linmark Associates v. Township of

governing function."), with The Supreme Court, 1979 Term, supra note 9, at 166 ("Since commercial messages necessarily contain social and political implications, they possess the same potential as other forms of speech to challenge those in political power and constitute a portion of the public dialogue on policy issues." (footnote omitted)).

Finally, the Court suggested that commercial speech should be protected because no workable line could be drawn protecting only advertising with high public interest content and no other. Any advertiser could insert a public interest element into his message. 425 U.S. at 764-65. Commentators have argued, however, that the line-drawing problem is not in practice a serious one, in any case not serious enough to justify abandoning the distinction entirely. T. Emerson, Toward a General Theory of the First Amendment 105 n.46 (1966); Jackson \& Jeffries, supra note 9, at 19-20. See also Judge Frank's opinion dissenting from the Second Circuit decision in Chrestensen v. Valentine:

We should not be disturbed because, in the future, cases may arise where there will

be some difficulty in ascertaining the primary purpose in distributing a handbill, and, because, when such cases arise, the courts may not be able to stop at locating merely the north and south poles of the subject matter, but may be required to do a more precise job of legal map-making and to fix a definite equatorial line. Where to draw such lines

"is the question in pretty much everything worth arguing in the law," Mr. Justice Holmes often noted.

122 F.2d 511, 520 (2d Cir. 1941) (quoting Irwin v. Gavit, 268 U.S. 161, 168 (1925)), rev'd, 316 U.S. 52 (1942).

43. The Court listed maintenance of professionalism, of high standards of quality, and of stable pharmacist-customer relationships. 425 U.S. at 766 70 .

44. Id. at 769-70, 773. The argument was less emphatically foreshadowed in Bigelow. There, the Court stated merely that a state interest in "shielding its citizens from information" about services available in other states "was entitled to little, if any, weight." Bigelow v. Virginia, 421 U.S. $809,827-28$ (1975).

45. 425 U.S. at 770.

46. Id. Justice Rehnquist has questioned whether people will indeed act in their own long-run best interests merely because more information is made available to them. He suggests that often the short-run interests of individuals may not coincide with the long-run interests of society, that people may well pursue the former rather than the latter, and that "this is a consideration that the government may properly take into account." Central Hudson Gas \& Elec. Corp. v. Public Serv. Comm'n, 447 U.S. 557, 593 n.5 (1980) (Rehnquist, J., dissenting).

47. Virginia Board did not foreclose "mere time, place, and manner" restrictions on speech. Such restrictions in this context must be content-neutral, must serve a significant government interest, and must leave open ample alternate channels for communication. 425 U.S. at 771. 
Willingboro ${ }^{48}$ for example, the Court struck down a town ordinance banning "For Sale" signs on all but model homes, a regulation aimed at forestalling panic selling in a racially changing community. The Court quoted the language of Bigelow calling for a "weighing" of interests, ${ }^{49}$ but found that even the "vital" goal advanced by the town in Linmark simply could not be achieved, consistently with the first amendment, by restricting the free flow of truthful information. ${ }^{50}$ The Court went on, in Carey v. Population Services International, ${ }^{51}$ to strike down a ban on the advertisement of contraceptives, ${ }^{52}$ and in Bates $v$. State Bar of Arizona, ${ }^{53}$ to strike down a ban on truthful newspaper advertising of the availability and terms of routine legal services..$^{54}$ The Court in Bates suggested that since the challenged rule served to inhibit the free flow of commercial information and kept the public in ignorance, its unconstitutionality flowed a fortiori from the decision in Virginia Board..$^{55}$ By 1978, unqualified protection for truthful and nonmisleading commercial speech seemed a reasonably settled matter..$^{56}$

\section{The Retreat from Protection}

In the cases following Bates, the Court signalled a retreat from its protection of commercial speech. In Ohralik v. Ohio State Bar Association, ${ }^{57}$ the Court, emphasizing the "limited measure of protection" afforded commercial speech, ${ }^{58}$ held that entire classes of commercial speech, necessarily including some harmless speech, could be prohibited where allowing the speech would be likely to result in some deception or overreaching because of difficulties in policing. ${ }^{59}$

48. 431 U.S. 85 (1977).

49. Id. at 91 .

50. Id. at 94-97.

51. 431 U.S. 678, 700-02 (1977).

52. The Carey holding was, however, based at least in part on the finding that the sale of contraceptives had independent constitutional protection. 431 U.S. at 687-88, 700-01.

53. 433 U.S. 350 (1977).

54. Id. at 384 .

55. Id. at 365 .

56. For a 1978 statement of the law, see L. Tribe, supra note 17, at 663 n.51 ("Truthful statements which are neither misleading nor obscene are protected by the first amendment even though made for a commercial purpose."').

57. 436 U.S. 447 (1978).

58. Id. at 456 .

59. Id. at 464-67. There had been some fears after Virginia Board that the ability of federal agencies such as the FDA and FTC to impose blanket prophylactic rules prohibiting various claims or phrases would be taken away, and that only closely drawn standards would be acceptable. See Reich, Preventing Deception in Commercial Speech, 54 N.Y.U. L. Rev. 775, 775-79 (1979); Comment, supra note 28, at 808 n.58; Note, Yes, FTC, There is a Virginia: The Impact of Virginia State Board of Pharmacy v. Virginia Citizens Consumer Council, Inc. on the Federal Trade Commission's Regulation of Misleading Advertising, 57 B.U. L. Rev. 833, 850 (1977) (proposing the standard of "advertising that a reasonable person could interpret as making a false assertion"). Such limited regulation, though, seemed inadequate. See Cox, supra note 6, at 32. Ohralik and Friedman v. Rogers, 440 U.S. 1 (1979), freed the regulators of the fear that they might be held to so strict a standard. See, e.g., United States v. Reader's Digest Ass'n, Inc., 662 F.2d 955, 965 (3d Cir. 1981), cert. denied, 102 S.Ct. 1253 (1982); Jay Norris, Inc. v. FTC, 598 F.2d 1244, 1252 (2d Cir.), cert. denied, 444 U.S. 980 (1979). See generally Federal Trade Commission Act $\S \S 5,12,15,15$ U.S.C. $\S \S 45,52,55$ (1976). 
After its approval in Ohralik of broad prophylactic restrictions reaching even harmless speech, the Court in Friedman v. Rogers ${ }^{60}$ sharply expanded the definition of potentially harmful speech. There, the Court upheld a statute banning any use of trade names by optometric offices, on the ground that "there is a significant possibility that trade names will be used to mislead the public." 61 The Court also suggested that trade names might be legitimately banned because large-scale commercial optometric practice constitutes "conduct the State rationally may wish to discourage while not prohibiting . . . altogether," and the prohibition of trade names was a means toward that end. ${ }^{62}$ The suggestion marked a distinct retreat from the Virginia Board and Linmark rejections of "paternalism," ${ }^{63}$ implying that the state can in fact protect its citizens by keeping information from them. ${ }^{64}$

The Friedman holding set the stage for the Court's explicit statement in Central Hudson Gas \& Electric Corp. v. Public Service Commission ${ }^{65}$ that the state may indeed, using narrowly drawn restrictions, suppress commercial speech solely in order to dampen demand for a legitimate product. In Central Hudson, the Court considered a New York Public Service Commission rule prohibiting electrical utilities subject to its jurisdiction from running advertisements that promoted or stimulated electricity consumption. ${ }^{86}$ Although the

60. 440 U.S. 1 (1979).

61. Id. at 12-13. The challenged Texas statute prohibited the practice of optometry under a trade name, requiring that optometric offices be identified only by the names of the optometrists practicing there. Its effect was to leave intact the "professional" practice of optometry in Texas, but to eliminate the "commercial" practice, in which an organization would franchise out optometric offices around the state under a single name, operating on a high-volume, low-cost basis.

The case was treated as one involving commercial speech, on the ground that trade names may identify the good or service they represent and convey information about the type, price, and quality of that good or service, and as such are used as part of a proposal of a commercial transaction. Id. at 11. The Court reasoned that trade names have no intrinsic meaning but acquire "ill-defined associations" in the minds of the public with price and quality information, that these associations can be "manipulated" by the users of the trade names, and that as a result the use of trade names is conducive to deception and may be prohibited. Id. at 12-13. The standard laid down seems a tremendously broad definition of what constitutes misleading speech; if trade names under this analysis can be found to be misleading, it is hard to imagine what could not be. See Cox, supra note 6 , at 33 .

62. 440 U.S. at 13 .

63. The Court in dictum resurrected the concept of ad hoc balancing in commercial speech adjudication, characterizing Virginia Board as a case where the important state interest in pharmacists' professionalism was outweighed by the first amendment interests in the information conveyed. Id. at 8-9.

64. One commentator has suggested that the key to the Court's decision in Friedman is "the futility of attempting to maintain a general constitutional distinction between commercial advertising and other commercial activity." Given that Texas could easily have achieved its goal through a direct prohibition of commercial optometric practice rather than a prohibition of its advertising, the Court was unwilling to hold that one means was legitimate and the other not. Cox, supra note 6 , at 33 .

65. 447 U.S. 557 (1980).

66. The Public Service Commission (PSC) maintained that such advertising was contrary to the national policy of conserving energy. It worried that the advertising would send "misleading signals" to the public at a time when energy conservation was called for. 447 U.S. at 558-60. Of the Court, only Justice Rehnquist gave any weight to the fact that the speaker in this case was a public utility, a state-created monopoly. He suggested that such an entity is, for first amendment purposes, "far closer to a state-controlled enterprise than is an ordinary corporation," and is subject to "a special duty to conform its conduct to the [PSC's] conception of the public interest." 447 U.S. at 587-88 (Rehnquist, J., dissenting). 
Court struck down the specific regulation at issue as overly broad, ${ }^{67}$ it endorsed such regulations of nonmisleading speech generally. The Court announced that nonmisleading commercial speech concerning lawful activity may constitutionally be subjected to regulation directly advancing a substantial state interest, so long as the regulation is no more extensive than necessary to serve that interest. ${ }^{68}$ The Court drew no distinction between regulations directly aimed at the content of the speech, and those concerned only with the manner of its exercise. ${ }^{69}$ In so doing, it rejected the absolute rule of Linmark, ${ }^{70}$ and legitimized a degree of regulation of nonmisleading commercial speech that would be an anathema in any other area ${ }^{71}$ of first amendment jurisprudence. ${ }^{72}$

The Court's requirement that commercial speech regulation be no more extensive than necessary, however, a "least restrictive means" standard, can in the discretion of the Court be made impossible to meet. One can always find, in challenging a regulation, a slightly less "drastic" or "restrictive" alternative. ${ }^{73}$ The Court thus gave with one hand and took away with the other; while commercial speech restrictions may have little trouble surviving the substantial-state-interest test, they are subject as well to a least-restrictivemeans test that the Court has the power either to emphasize or to ignore. ${ }^{74}$

67. The Court found that "[i]n the absence of authoritative findings to the contrary, we must credit as within the realm of possibility" the claim that some advertising of electric services might not detract from the cause of energy conservation. 447 U.S. at 570 . The finding has been characterized as a striking substitution of judicial opinion for state regulatory authority. Cox, supra note 6 , at 35 .

68. 447 U.S. at $564,566$.

69. Professor Tribe would treat restrictions in the first category as "presumptively at odds with the first amendment," while subjecting restrictions in the second category only to a balancing test. L. Tribe, supra note 17 , at 580-81. The Court's rule subjects restrictions in both categories to the same test, and has in fact been applied by the lower courts to restrictions in both categories. See infra text accompanying notes 75-76.

70. Justice Blackmun, concurring in Central Hudson, saw the Court's test as an appropriate one for "time, place, and manner" restrictions, but asserted that Linmark precluded suppression, except pursuant to a strict standard of review, where the state's goal was to suppress truthful, nondeceptive information in order to manipulate private economic decisions. 447 U.S. at 573-78.

71. Sexually explicit speech might be an exception. See generally Young v. American Mini Theatres, Inc., 427 U.S. 50 (1976); New York State Liquor Auth. v. Bellanca, 452 U.S. 714 (1981) (per curiam).

72. Justice Rehnquist, dissenting, complained that the new rule accords commercial speech a level of protection that is "virtually indistinguishable from that of noncommercial speech," 447 U.S. at 591, but he was surely wrong in that assessment. A restriction on political speech aimed directly at suppressing the information and ideas conveyed by that speech could not be justified without some showing of compelling necessity, or clear and present danger. Consolidated Edison Co. v. Public Serv. Comm'n, 447 U.S. 530, 535-40 (1980); First Nat'l Bank v. Bellotti, 435 U.S. 765, 786 (1978); Bates v. Little Rock, 361 U.S. 516, 524 (1960); Whitney v. California, 274 U.S. 357, 373 (1927) (Brandeis, J., concurring); L. Tribe, supra note 17, at 582.

73. Illinois State Bd. of Elections v. Socialist Workers Party, 440 U.S. 173, 188-89 (1979) (Blackmun, J., concurring), quoted in Central Hudson, 447 U.S. at 600 (Rehnquist, J., dissenting).

74. One year after Central Hudson, the Court handed down a decision in Metromedia, Inc. v. City of San Diego, 453 U.S. 490 (1981), in which it ignored the question of least restrictive means. The Court there considered a challenge to a San Diego billboard ordinance prohibiting all "outdoor advertising display signs" except for on-site signs (those identifying the premises on which they are placed, or advertising goods and services sold there) and others described in narrow exceptions. Id. at 493-94. The plurality, though striking down the ordinance, held it constitutional as applied to commercial speech only. It deferred to the city's judgment as "not 
The Court has thus created a shifting rule of law that may lead to little more than ad hoc adjudication. The lower courts, in assessing challenges to "time, place, and manner" restrictions on nonmisleading commercial speech, have tended to apply Central Hudson and uphold the restriction; ${ }^{75}$ in assessing challenges to restrictions on content they have tended to strike down the restriction, sometimes citing Central Hudson and sometimes ignoring it entirely. ${ }^{76}$ In so doing, they have in practice drawn the distinction that the Court refused to draw. Such application of a Supreme Court rule, however, is healthy neither for the bar nor for the advertisers being regulated. ${ }^{77}$

\section{PROTECTED INTERESTS AND UNDERLYING VALUES}

The first amendment protects three distinct interests: those of the speaker, the listener, and the communications process itself. ${ }^{78}$ Each interest

manifestly unreasonable," id. at 509 , and dismissed in a single short paragraph the argument that there existed means less restrictive than a total ban on off-site commercial billboards of achieving the city's traffic safety goal. Id. at 508.

The plurality went on to reason that the presence of the on-site exception meant that the ordinance afforded a greater degree of protection to commercial than to noncommercial speech, and that this was constitutionally impermissible, since commercial speech must be granted less protection than noncommercial speech, rather than more. Id. at 513. It further found that the narrow exceptions for time-of-day signs and the like violated the principle of content-neutrality, and that the ordinance must fall on that ground as well.

75. See, e.g., Ad. World, Inc. v. Township of Doylestown, 510 F. Supp. 851 (E.D. Pa. 1981), cert. denied, 50 U.S.L.W. 3916 (U.S. May 17, 1982); May v. Colorado, 636 P.2d 672 (Colo. 1981). But see In re Greene, 54 N.Y.2d 118, 126-27, 429 N.E.2d 390, 394, 444 N.Y.S.2d 883, 887 (1981), cert. denied, 50 U.S.L.W. 3766 (U.S. Mar. 23, 1982), implying that the Central Hudson four-part analysis is not necessary unless the regulation is found to be content-based.

76. See, e.g., Bolger v. Youngs Drug Prods. Corp., 526 F. Supp. 823 (D.D.C. 1981), prob. juris. noted, 50 U.S.L.W. 3915 (U.S. May 17, 1982) (No. 81-1590); Oklahoma Telecasters Ass'n v. Crisp, No. Civ-81-439-W, slip op. (W.D. Okla. Feb. 10, 1982) (available Apr. 26, 1982 on LEXIS, Genfed library, Dist file); Illinois Ass'n of Realtors v. Village of Bellwood, 516 F. Supp. 1067 (N.D. Ill. 1981) (Central Hudson available but nowhere cited); Equifax Services v. Cohen, 420 A.2d 189 (Me. 1980), cert. denied, 450 U.S. 916 (1981).

77. The Court most recently spoke to questions of commercial speech in In re R.M.J., $102 \mathrm{~S}$. Ct. 929 (1982). It there reversed a state bar association disciplinary action punishing an attorney for placing advertisements in which he listed the jurisdictions in which he was licensed to practice, stated that he was a member of the Supreme Court bar, and deviated from state-prescribed language in describing his areas of practice, as well as for mailing out cards announcing the opening of his office to the general public. The Court held that in the absence of any lower court finding that the attorney's actions were inherently or in fact misleading, and in the absence of any suggestion that the restrictions served other substantial state interests, the restrictions could not stand. Id. at 939.

Litigation in the commercial speech area is continuing. See, e.g., Bolger v. Youngs Drug Prods. Corp., 526 F. Supp. 823 (D.D.C. 1981) (statute banning unsolicited advertisements for contraceptives violates first amendment), prob. juris. noted, 50 U.S.L.W. 3915 (U.S. May 17, 1982) (No. 81-1590); Princess Sea Indus. v. Nevada, 635 P. 2d 281 (Nev. 1981) (state may constitutionally restrict advertising of brothels even in counties where prostitution is legal), cert. denied, 50 U.S.L.W. 3838 (U.S. Apr. 20, 1982).

78. Cf. Kleindienst v. Mandel, 408 U.S. 753, 775 (1972) (Marshall, J., dissenting) ("'T]he First Amendment protects a process, ... . and the right to speak and hear . . . are inextricably part of that process. The freedom to speak and the freedom to hear are inseparable; they are two sides of the same coin. But the coin itself is the process of thought and discussion."). 
reflects an aspect of communication that is crucial if there is to be communication at all-there can hardly be speech without a speaker; that speaker's speech is pointless without one to hear and appreciate it; and it is unavailing to have willing speakers and eager listeners if the process of communication itself is clogged.

Underlying the protection of any expression are four basic values: political self-government, self-realization through expression, discovery of truth, and individual growth through perception. Combined, the interests and the values provide a framework for first amendment analysis: ${ }^{79}$ the interests determining the scope of permissible restrictions on protected speech, and the values determining ${ }^{80}$ what sorts of speech are to be protected..$^{81}$

79. The values play a crucial role in first amendment analysis because the first amendment cannot be read to protect "speech" defined in entirely nonfunctional terms. The existence, without constitutional controversy, of statutes criminalizing conspiracy, solicitation of crime, perjury, espionage, and the like suffice to prove this. Rather, only speech implementing basic first amendment values is speech that deserves protection. See Konigsberg v. State Bar, 366 U.S. 36, 49 \& n.10 (1961); T. Emerson, supra note 42, at 430-31; Jackson \& Jeffries, supra note 9, at 8-9.

In the area of commercial speech, Professors Jackson and Jeffries have explicitly undertaken this sort of analysis. See Jackson \& Jeffries, supra note 9, at 1-25; see also Chrestensen v. Valentine, 122 F.2d 511, 525 (2d Cir. 1941) (Frank, J., dissenting) (Protecting commercial speech "would be to 'thingify' the words 'free speech' and 'free expression', and to become forgetful of the vital ideas . . . for which they stand."). But see L. Tribe, supra note 17, at 576:

[F]reedom of speech [should not] be regarded only as a means to some further end. . . .

[It is] in part also an end in itself, an expression of the sort of persons we wish to be. . . .

No adequate conception of so basic an element of our fundamental law . . . can be developed in purely instrumental or "purposive" terms.

Cf. CBS v. Democratic Nat'l Comm., 412 U.S. 94, 145 (1973) (Stewart, J., concurring) ("When we lose sight of the First Amendment itself, and march forth in blind pursuit of its 'values," "we run the risk of diluting essential protections.).

Judge (then Professor) Bork, while recognizing that a number of values could arguably be found to underlie the amendment, would draw what he considers to be the most clear-cut and workable line at the "outer limits of political speech." Bork, Neutral Principles and Some First Amendment Problems, 47 Ind. L.J. 1, 27-28 (1971). Professor Schauer would categorize valueoriented first amendment analysis as exhibiting a "defining in" rather than a "defining out" perspective. Schauer, Categories and the First Amendment: A Play in Three Acts, 34 Vand. L. Rev. 265, 281-82 (1981). For an example of a "defining out" approach, see Schiro, supra note 17, at 93.

80. The values are to some degree overlapping and amorphous; in general more than one value is implicated by any given example of speech. This makes it difficult to discover direct support in the cases for a theory based on reasoning from underlying values. Where speech advances both value $A$ and value $B$, one cannot tell for sure whether one of the values might not be wholly irrelevant, and the other the basis for protection. Even with this limitation, however, a value-based structure provides a useful analytical framework on which to build first amendment analysis.

81. It seems safe to say that advertising was not speech specifically intended to be protected by the Framers. See Bates v. State Bar of Arizona, 433 U.S. 350, 404 (1977) (Rehnquist, J., dissenting in relevant part). It appears, though, that the Framers in fact had no coherent theory of free speech, and paid little attention to the issue. See L. Levy, Legacy of Suppression: Freedom of Speech and Press in Early American History (1960); Bork, supra note 79, at 22. Just as no specific meanings were intended, it appears likely that virtually no particular meanings were foreclosedthe very vagueness of the text was intended to delegate to future generations the task of developing an exact meaning. See BeVier, The First Amendment and Political Speech: An Inquiry Into the Substance and Limits of Principle, 30 Stan. L. Rev. 299, 307 (1978). 


\section{A. Interests Protected}

1. Speaker Interests. The Supreme Court has traditionally approached first amendment analysis by focusing on the interests of the speaker. ${ }^{82}$ Where the first amendment is viewed as guaranteeing a constitutional right to free expression, the speaker is the actor naturally associated with that right. ${ }^{83}$ For example, where speech serves to create unrest and dispute, ${ }^{84}$ it is the speaker who is asserting a right to provoke and distress others. Similar emphasis on the speaker interest is apparent, for example, in Professor Baker's assertion that speech is protected to the degree that it is "a manifestation of individual freedom and choice." 85

First amendment analysis focusing on the speaker interest yields two important results. First, no considerations of redundancy can apply-protection for speech can never be denied on the ground that the same communication is being made, or has been made, equally well by someone else. ${ }^{80}$ Especially where the protection given to the speaker is based on his own selfrealization, achieved through his speech, protection cannot be diminished because some other speaker is conveying the same ideas and information. Focusing only on the speaker's personal interests in speaking, first amendment analysis must proceed without regard to the speech of others.

Second, in considering speech implicating the speaker interest, the proper standard is a subjective one, focusing on the mind of the speaker. The speaker's motivation is crucial. Chrestensen, where the Court upheld an ordinance banning the distribution of advertising matter on the ground that an advertiser's motivation is purely commerical, can thus be explained as a case where the speaker's improper motivation negated any speaker interests that the advertiser might have asserted. The Chrestensen Court erred, though, in assuming that no further inquiry into other protected interests was neces-

82. See Emerson, supra note 30, at 464: "[T] me main thrust of the system of freedom of expression has always been to secure the right to communicate," since if that is secured then protection of other interests will normally follow.

83.

The constitutional right of free expression [is designed to put] the decision as to what views shall be voiced largely into the hands of each of us . . . in the belief that no other approach would comport with the premise of individual dignity and choice upon which our political system rests.

Cohen v. California, 403 U.S. 15, 24 (1971).

84. See Terminiello v. Chicago, 337 U.S. 1,4 (1949).

85. Baker, Commercial Speech: A Problem in the Theory of Freedom, 62 Iowa L. Rev. 1, 3 (1976). See also Z. Chafee, Free Speech in the United States 33 (1941) (The first amendment protects "the need of many men to express their opinions on matters vital to them if life is to be worth living."); infra notes 127-30 and accompanying text. But see Meiklejohn, The First Amendment is an Absolute, 1961 Sup. Ct. Rev. 245, 255 ("The First Amendment does not protect a 'freedom to speak.' It protects the freedom of those activities of thought and communication by which we 'govern'. . . "), quoted in Hynes v. Mayor of Oradell, 425 U.S. 610, 627 n.3 (1976) (Brennan, J., concurring).

86. See L. Tribe, supra note 17, at 603-04. Contrast the attitude of Professor Meiklejohn, who did not recognize speaker interests and argued that "[w] hat is essential is not that everyone shall speak, but that everything worth saying shall be said." A. Meiklejohn, supra note 38, at 25. In the area of broadcast regulation, where speaker interests do not control, a redundancy principle has been implicitly adopted. Compare Red Lion Broadcasting Co. v. FCC, 395 U.S. 367 (1969), with Buckley v. Valeo, 424 U.S. 1, 48-49 (1976). 
sary. While protection of speaker interests is often sufficient to safeguard threatened first amendment rights, ${ }^{87}$ it is, without more, inadequate to reflect the full spectrum of values ${ }^{88}$ underlying the first amendment.

2. Listener Interests. The existence of a protected listener interest seems well established, although the interest has received comparatively little attention in the case law. The existence of a listener interest was first asserted by the Court in dictum; ${ }^{89}$ it first became the basis for Court holdings in cases extending protection to political discussion where the speaker could assert no first amendment right himself. Thus, in Lamont $v$. Postmaster General, ${ }^{90}$ the Court struck down a statute burdening the receipt of "communist political propaganda" from abroad; ${ }^{91}$ in Kleindienst $v$. Mandel, ${ }^{92}$ the Court found that first amendment interests were infringed by a Justice Department refusal to admit a nonresident alien invited to participate in political colloquia and debates. ${ }^{93}$ In both these cases, in which the foreign speaker could assert no right to disseminate his speech in this country, ${ }^{94}$ the Court emphasized the existence of a first amendment interest belonging to the recipient of the speech, ${ }^{95}$ a "right to 'receive information and ideas." " 98

The Court has asserted listener interests in other cases as well, although some of these instances are arguably more concerned with privacy than with expression. For example, in Stanley v. Georgia ${ }^{97}$ the Court invoked a listener

87. See supra note 82 .

88. See infra text accompanying notes 118-66.

89. In some cases, the Court found a listener interest where the speech would in any case be protected because of speaker interests. See Thomas v. Collins, 323 U.S. 516, 533-34 (1945) (the right to hear labor speech is part of, and necessary to, the right of labor assembly); Martin v. City of Struthers, 319 U.S. 141, 143 (1943) (the "right to receive" literature is a first amendment right; free exercise also implicated); see also Griswold v. Connecticut, 381 U.S. 479, 482 (1965) ("the right to receive, the right to read" protected by the first amendment); Thornhill v. Alabama, 310 U.S. 88, 102 (1940) (emphasizing "the public need for information and education with respect to the significant issues of the times").

90. 381 U.S. 301 (1965).

91. Lamont can be read as a decision imposing limits upon the government's power to snoop through the mails, perhaps foreshadowing later privacy doctrines. This element, strongly present in Procunier v. Martinez, 416 U.S. 396 (1974), discussed infra notes 99-102 and accompanying text, was probably less important here, since the statute in Lamont was limited to unsealed mail. 381 U.S. at 302.

92. 408 U.S. 753 (1972).

93. Mandel, a Belgian journalist, had been denied an entry visa under 8 U.S.C. $\S 1182(a)(28)(D)(1976)$, banning from the United States "[a]liens . . . who advocate the economic, international, and governmental doctrines of world communism." Id. at 755. The Court, after acknowledging the first amendment rights of professors who sought to listen to Mandel, held the exclusion proper in light of Congress's plenary powers to regulate alien affairs.

Justice Marshall, arguing for Mandel's admission, relied in part on “appellees' personal rights both to hear Mandel's views and to develop and articulate their own views through interaction with Mandel." 408 U.S. at 776 (Marshall, J., dissenting).

94. See Johnson v. Eisentrager, 339 U.S. 763, 781-85 (1950).

95. Justice Brennan, concurring in Lamont, emphasized that "[t]he dissemination of ideas can accomplish nothing if otherwise willing addressees are not free to receive and consider them." 381 U.S. at 308. According to Justice Brennan, a right to hear flows necessarily from a right to speak-speakers are nothing without listeners. The argument, accepted by the plurality in Board of Educ., Island Trees Union Free School Dist. v. Pico, 50 U.S.L.W. 4831, 4835 (U.S. June 24, 1982), but correctly rejected by Justice Rehnquist in dissent, id. at 4847 , is flawed. Given that the speaker in Lamont had no right to speak, it was useless to say that a right to speak will generate corresponding rights to hear. Any listener interest must have had an independent basis.

96. Mandel, 408 U.S. at 762.

97. 394 U.S. 557 (1969). 
interest in order to constitutionalize a right to private possession of obscene materials, ${ }^{98}$ and in Procunier $v$. Martinez,${ }^{99}$ it struck down restrictions on letter writing by prison inmates ${ }^{100}$ without reaching the question of the inmates' own first amendment rights. ${ }^{101}$

By 1976, the Court in Virginia Board could describe the existence of a general right to receive information and ideas from a willing speaker as "clear," 102 although the Court may have claimed to find somewhat more clarity in the cases than was apparent. Recently, it has invoked the interest without hesitation. ${ }^{103}$

Where speech implicates only listener interests, the first amendment provides a different sort of protection than where speaker interests are implicated. First, since the emphasis is on what reaches the listener, "redundant" speech is not protected. If a particular idea will reach the same audience even though an individual speaker is gagged, there is nothing in the listener interest to preclude such restraint. ${ }^{104}$ Similarly, a mode of communication may be blocked if the speech is likely to reach the listener in some other form. ${ }^{105}$

98. The Court cited a "right to receive information and ideas." Id. at 564. It was protecting no speaker interest in the dissemination of obscene material, since no such interest exists. Similarly, it was protecting no "marketplace" interest, because obscene material has been held not to contribute to the marketplace of ideas. Roth v. United States, 354 U.S. 476 (1957). Thus, if the Court was protecting any first amendment interest at all, it was protecting the recipient's interests. The Court, however, based its holding in part on privacy interests, and it seems likely that the decision rested largely on its privacy leg and rather less on its right-to-receive leg. See Roe v. Wade, 410 U.S. 113, 152 (1973) (Stanley located the "roots" of a right of personal privacy in the first amendment). But see Whalen v. Roe, 429 U.S. 589, 609 (1977) (Stewart, J., concurring) (Stanley essentially concerned not with privacy but with a "right to read").

99. 416 U.S. 396 (1974).

100. At stake were California prison rules prohibiting inmates from writing letters in which they "unduly complain" or "magnify grievances," which express "inflammatory" beliefs, or which "pertain to criminal activity; are lewd, obscene, and defamatory; contain foreign matter, or are otherwise inappropriate." Id. at 399-400.

101. The Court stated that it need not "deal ... with difficult questions of the so-called 'right to hear," "id. at 409 , but based its holding in part on the argument that "[t]he wife of a prison inmate who is not permitted to read all that her husband wanted to say to her has suffered an abridgment of her interest in communicating with him." Id. In addition, the Court hinted that it was relying on process interests, see infra text accompanying note 111 .

It seems likely that some members of the Court may have considered privacy interests at stake here, though none were asserted.

102. Virginia State Bd. of Pharmacy v. Virginia Citizens Consumer Council, Inc., 425 U.S. 748, 756 (1976).

Justice Rehnquist, in dissent, argued that a right to receive should only be found where the would-be recipients could not reasonably receive the information through some other means. Id. at 782 . General listener-interest analysis dictates that no right to receive a specific communication should be found unless acknowledging such a right will increase the degree to which the ideas or information in question will get through to the listeners, see text following this note; see also Board of Educ., Island Trees Union Free School Dist. v. Pico, 50 U.S.L.W. 4831, 4847 (U.S. June 24, 1982) (Rehnquist, J., dissenting). Recognition of a listener's right to receive drug price advertising, however, will increase the degree to which the information gets through when compared to consumers' abilities to call up all local drugstores and obtain the information themselves.

103. See Board of Educ., Island Trees Union Free School Dist. v. Pico, 50 U.S.L.W. 4831 (U.S. June 24, 1982); First Nat'l Bank v. Bellotti, 435 U.S. 765, 781-83 (1978).

104. See A. Meiklejohn, supra note 38.

105. Cf. generally Young v. American Mini Theatres, Inc., 427 U.S. 50, 62 (1976), where the Court found, and emphasized, that a Detroit ordinance restricting adult theatres still left enough sites for adult theatres to accommodate all patrons. Professor Tribe has argued that the theatres 
Second, the motivation and identity of the speaker are irrelevant. From the point of view of the listener, the value of the speech lies only in its content. ${ }^{106}$

3. The Process Interest. In addition to speaker and listener interests, several Supreme Court opinions manifest an independent interest in maintaining the structure that permits communication. Protection of the communications process can be most readily seen in the Court's broadcast regulation cases, notably Red Lion Broadcasting Co. v. FCC, ${ }^{107}$ in which the Court upheld the fairness doctrine against first amendment challenge. ${ }^{108}$ The Court's decision in Red Lion cannot be satisfactorily explained by the presence of either speaker interests ${ }^{109}$ or listener interests; ${ }^{110}$ rather, the focus is on protecting the integrity of the medium, in establishing a working marketplace of ideas in the radio spectrum. Similar protection for another concrete process of communication may be found in Procunier, where the Court at one point purported to rely not on listener interests as such, but on the fact that the government had interfered with the process of communication through the mails, "a particular means of communication in which the interests of both parties are inextricably meshed." "ג1

The Court, however, has expanded the scope of the process interest beyond the protection of specific, concrete vehicles for communication. It has recognized the importance of the interest in protecting the communications process in its broadest sense, in the form of the general marketplace of ideas. Thus, in Mandel, where the issue was admission of a journalist into the country to participate in a series of colloquia and debates, ${ }^{112}$ Justice Marshall's dissenting opinion described the Court as correctly finding that a "general public interest" in "the process of thought and discussion" had been infringed, an interest distinct from that of a speaker or a listener. ${ }^{113}$

were granted a lower standard of protection in Young because the Court recognized no speaker interest, only a "generalized 'right to know' of the viewing public." L. Tribe, supra note 17, at 676-77. But see Schad v. Borough of Mt. Ephraim, 452 U.S. 61 (1981) (zoning ordinance prohibiting live entertainment in any form not saved by the fact that entertainment is available in nearby areas).

106. See First Nat'l Bank v. Bellotti, 435 U.S. 765, 777 (1978). The Court there made it plain, see id. at $782 \mathrm{n} .18$, that it sought to protect listener interests.

107. 395 U.S. 367 (1969).

108. The Court held that because of the limited number of frequencies available for public broadcasting, "it is idle to posit an unabridgeable First Amendment right to broadcast." Id. at 388. Since the broadcast licensee may have no more "right" to a license than a nonlicensee, the government may require the broadcaster to act as a "proxy or fiduciary" to present community views and voices that would not otherwise enjoy access to the electronic media. Id. at 389.

The Court went beyond that, however, to find that the first amendment affirmatively mandates the fairness doctrine. Citing "the right of the public," it emphasized that "[i]t is the purpose of the First Amendment to preserve an uninhibited marketplace of ideas in which truth will ultimately prevail, rather than to countenance monopolization of that market." Id. at 390.

109. The Court was not protecting the rights of outside speakers, because the thrust of the fairness doctrine is to award a reasonable amount of broadcast time to opposing viewpoints rather than to opposing speakers. Id. at 391 . Thus, depending on circumstances, a particular speaker may be able to assert no first amendment broadcast right at all.

110. Although the Court spoke of "the right of the viewers and listeners" as paramount to "the right of the broadcasters," id. at 390, that right alone would not justify placing an affirmative obligation on broadcasters to disseminate speech with which they disagree.

111. Procunier v. Martinez, 416 U.S. 396, 409 (1974). For discussion of Procunier, see supra notes 99-101 and accompanying text; infra note 159 .

112. See supra notes $92-93$ and accompanying text.

113. 408 U.S. 753, 775-76 (1972) (Marshall, J., dissenting). 
The process interest, like the listener interest, yields protection that is limited in scope. Redundant speakers need not be protected; if an idea is wellrepresented in the marketplace, the right of other speakers to champion it need not be protected. ${ }^{114}$ Further, there is a tendency under the process interest to deny protection to marginal listeners, i.e., those listeners whose contribution to the communications marketplace of ideas is seen to be outweighed by the burden on the process of allowing them a right to receive. ${ }^{115}$ Finally, the motivation and identity of the speaker are unimportant: ${ }^{116}$ neither has any effect on the value of the speech in the marketplace. ${ }^{117}$

\section{B. Values Promoted}

1. Political Self-Government. An important purpose of the first amendment is to protect the free discussion of political and governmental affairs. ${ }^{118}$ Because political speech "is more than self-expression; it is the essence of selfgovernment," 119 the Supreme Court has frequently identified self-government as the central social value advanced by the first amendment. ${ }^{120}$

\section{See A. Meiklejohn, supra note 38 , at 25 :}

The First Amendment . . . does not require that, on every occasion, every citizen shall take part in public debate. Nor can it even give assurance that everyone shall have the opportunity to do so. If, for example, at a town meeting, twenty like-minded citizens have become a "party," and if one of them has read to the meeting an argument which they have all approved, it would be ludicrously out of order for each of the others to insist on reading it again.

115. In Gottfried v. FCC, 655 F.2d 297 (D.C. Cir. 1981), cert. granted, 102 S. Ct. 998 (1982) (No. 81-799), hearing-impaired plaintiffs, asserting a first amendment right of access to programming over the public airwaves, sued for a blanket requirement of television closed-captioning. Judge J. Skelly Wright answered that "[e]ven if the First Amendment entitles the hearing impaired to have access to some minimum of programming over the airwaves, however, we could not accept that it requires all stations to make their programming accessible to all deaf persons all of the time." Id. at 311 n.54. Judge Wright cited for that proposition a case upholding the denial of broadcast access to speakers, CBS v. Democratic Nat'l Comm., 412 U.S. 94, 111 (1973). The theoretical basis for denying broadcast access to speakers, however, cannot automatically be extended to affect the broadcast rights of listeners. The former rests strongly on the limited availability of broadcast frequencies, see Red Lion Broadcasting Co. v. FCC, 395 U.S. 367 (1969), a factor which does not apply here.

116. See First Nat'l Bank v. Bellotti, 435 U.S. 765, 777, 783 (1978).

117. Efforts to extend the idea that "regulation of the communications market [may] sometimes facilitate . . the exchange of information [and] ideas," Metromedia, Inc. v. City of San Diego, 453 U.S. 490, 548 (1981) (Stevens, J., dissenting), to regulation of political speech have been largely unsuccessful. See, e.g., Miami Herald Publishing Co. v. Tornillo, 418 U.S. 241 (1974) (striking down statute imposing obligation on newspaper to give political candidates "right of reply").

Justice White has championed the approach, claiming that regulation of speakers may be necessary to protect the marketplace. Dissenting in First Nat'l Bank v. Bellotti, 435 U.S. 765 (1978), he argued that the vast economic power of corporations, unrelated to the strength of the convictions of individual shareholders or officers, "may be viewed as seriously threatening the role of the First Amendment as a guarantor of a free marketplace of ideas," id. at 810. The Court, however, has rejected this approach. It has held that "the concept that government may restrict the speech of some elements of society in order to enhance the relative voice of others is wholly foreign to the first amendment," except in the context of broadcast regulation. Buckley $v$. Valeo, 424 U.S. 1, 48-49 (1976).

118. Mills v. Alabama, 384 U.S. 214, 218 (1966).

119. Garrison v. Louisiana, 379 U.S. 64, 74-75 (1964).

120. See First Nat'l Bank v. Bellotti, 435 U.S. 765, 771, 776-77 (1978); Buckley v. Valeo, 424 U.S. 1, 14 (1976); Monitor Patriot Co. v. Roy, 401 U.S. 265, 272 (1971); Grosjean v. American Press Co., 297 U.S. 233, 250 (1936); see also New York Times Co. v. Sullivan, 376 U.S. 254, 266 (1964). 
The political self-government value was the one most clearly in the minds of the Framers. ${ }^{121}$ Madison wrote of the necessity of "popular information [and] the means of acquiring it" if a popular government was to survive; "a people who mean to be their own Governors, must arm themselves with the power which knowledge gives." 122 Political speech is said to ensure that the government is intelligently run, ${ }^{123}$ that the "systematic integrity of our constitutional scheme of self-government" is preserved ${ }^{124}$ and that basic notions of freedom are upheld. ${ }^{125}$

Speech promoting the self-government value may advance speaker, listener, and process interests. The value implicates speaker interests because it safeguards the citizen's political right to political expression. Therefore, speech advancing the self-government value must be protected regardless of whether it repeats what others have said. In addition, the value implicates listener interests, through its goals of fostering the growth of the faculties equipping the individual to live as a citizen of a democratic state and furthering the citizen's ability to make informed choices when called upon to decide political issues. Finally, the value draws in the process interest, for robust political discussions and informed political choices are impossible without a protected marketplace in which different ideas can vie for acceptance. ${ }^{126}$

2. Self-Expression. A second basic value underlying the first amendment is that of individual self-fulfillment through expression. ${ }^{127}$ As argued by Professor Thomas Emerson, ${ }^{128}$ a basic premise of Western thought is that the goal of each individual should be the full realization of his character and potential as a human being. The formation of the individual's own beliefs and opinions is a crucial part of the development of his own personality, and expression is a basic element in "the development of ideas, ... mental

121. See Note, The Right to Know in First Amendment Analysis, 57 Tex. L. Rev. 505, 506-07 (1979).

122. Letter from James Madison to W.T. Barry (August 4, 1822), reprinted in Note, supra note 121 , at 506 .

Most contemporary colonial commentators saw freedom of speech as amounting to no more than freedom of press and petition, and thus encompassing little non-political speech. See Annals of Cong. 738 (1789); L. Levy, supra note 81, at 174.

123. See A. Meiklejohn, supra note 38 , at 26 ("Just so far as, at any point, the citizens who are to decide an issue are denied acquaintance with information or opinion or doubt or disbelief or criticism which is relevant to that issue, just so far the result must be ill-considered, ill-balanced planning for the general good.").

124. Jackson \& Jeffries, supra note 4 , at 11 .

125. The individual denied the opportunity to participate in his own government cannot be said to be free. See J.-J. Rousseau, The Social Contract 49-68 (Penguin ed. 1968).

126. The Court has, however, declined to apply to political speech the sort of regulation of the communications process that the marketplace metaphor is seen to mandate in the broadcast area. See supra note 117.

127. The idea in less elaborate form is an old one: Milton described licensing of the press as "the greatest displeasure and indignity to a free and knowing spirit that can be put upon him." J. Milton, Areopagitica, in Prose Writings 21 (Everyman's Library ed. 1927).

128. See generally T. Emerson, supra note 42; T. Emerson, The System of Freedom of Expression (1970) [hereinafter cited as T. Emerson, The System]; Emerson, supra note 30; Emerson, Toward a General Theory of the First Amendment, 72 Yale L.J. 877 (1963) [hereinafter cited as Emerson, Toward a General Theory]. 
exploration and ... the affirmation of self." 128 This general view was most notably advanced by Justice Douglas, who championed a reading of the first amendment designed to secure "the autonomous control over the development and expression of one's intellect, interests, tastes and personality." 130

The value of self-fulfillment through expression focuses solely on the role of the speaker in the communication process and thereby implicates exclusively speaker interests. The scope of protection thus associated with the value is quite broad. Protection can never be denied on the ground that some other speaker has made the point, or that other means of expression are available, or that room for other viewpoints must be left in the marketplace of ideas. ${ }^{131}$

Because the speaker interest is implicated, however, the speaker's motivation becomes relevant. To advance the self-realization value, speech must constitute a part of the development of the speaker's own personality through some form of mental exploration or self-affirmation. ${ }^{132}$ The value is thus a subjective one, and determinations of whether it is advanced can only be made by reference to the speaker's own mental processes. ${ }^{133}$

3. Discovery of Truth. The third value underlying protection of freedom of expression is that of the discovery of truth and advancement of knowledge. ${ }^{134}$ As with the political self-government value, the image is an old one: Milton, in the seventeenth century, pictured truth and falsehood grappling "in a free and open encounter." 135 John Stuart Mill argued that "the peculiar evil of silencing the expression of an opinion is that it is robbing the human race, posterity as well as the existing generation-those who dissent from the opinion, still more than those who hold it." ${ }^{138}$ The discovery value is firmly entrenched in first amendment jurisprudence, ${ }^{137}$ enshrined in the "marketplace of ideas" metaphor that is frequently invoked to protect the

129. Emerson, Toward a General Theory, supra note 128, at 879. See First Nat'l Bank v. Bellotti, 435 U.S. 765, 804-07 (1978) (White, J., dissenting); see also Baker, supra note 85; Z. Chafee, supra note 85 .

130. Roe v. Wade, 410 U.S. 113, 211 (1973) (Douglas, J., concurring) (emphasis omitted).

131. L. Tribe, supra note 17 , at 675 .

132. See Emerson, Toward a General Theory, supra note 128, at 879 . Many commentators have argued that commercial speech is not deserving of protection in part because it does not advance this value. See Jackson \& Jeffries, supra note 9, at 14 ("Whatever else it may mean, the concept of a first amendment right of personal autonomy in matters of belief and expression stops short of a seller hawking his wares."); infra text accompanying notes 168-70.

133. See supra text accompanying note 87 .

134. See generally Duval, Free Communication of Ideas and the Quest for Truth: Toward a Teleological Approach to First Amendment Adjudication, 41 Geo. Wash. L. Rev. 161 (1972).

135. Quoted in L. Tribe, supra note 17, at 576.

136. J.S. Mill, On Liberty 21 (Library of Liberal Arts ed. 1956) (1st ed. London 1859).

137. See Gertz v. Robert Welch, Inc., 418 U.S. 323, 339-40 (1974); Red Lion Broadcasting Co. v. FCC, 395 U.S. 367, 390 (1969); supra text accompanying notes 112-13. But see Central Hudson Gas \& Elec. Corp. v. Public Serv. Comm'n, 447 U.S. 557, 592 (1980) (Rehnquist, J., dissenting) ("While it is true that an important objective of the First Amendment is to foster the free flow of information, identification of speech that falls within its protection is not aided by the metaphorical reference to a 'marketplace of ideas.' "). 
dissemination of both ideas ${ }^{138}$ and information. ${ }^{139}$ As Justice Holmes stated in his dissent in Abrams $v$. United States, ${ }^{140}$

[W] hen men have realized that time has upset many fighting faiths, they may come to believe even more than they believe the very foundations of their own conduct that the ultimate good desired is better reached by free trade in ideas-that the best test of truth is the power of the thought to get itself accepted in the competition of the market ..... ${ }^{141}$

The discovery value transcends the mere participants in the communication; it advances the interests of the marketplace of ideas itself, and through that marketplace the interests of the human race as a whole. ${ }^{142}$ It thus reflects the process interest.

The discovery value protects the transmission of information as well as the expression of ideas and opinions. ${ }^{143}$ While the end served by the marketplace value is the discovery of truth in the realm of ideas, not that of facts, speech conveying factual information does advance the value because that speech provides the backdrop against which the search for ideological truth can be more effectively carried out. With more factual background present, the marketplace can better perform its function of ideological discrimination.

4. Development Through Perception. The fourth value protected by the first amendment is that of individual development through perception. ${ }^{144} \mathrm{It}$ is proposed that perception is at the core of personhood, and that the essence of the development of the individual is the integration of new information and ideas into the individual's own subjective world-picture. The individual mind grows by assimilating information and ideas from the outside and integrating them into a restructured cognitive framework. The protection of this individual development constitutes an underlying first amendment value; any majoritarian decision to limit the individual's ability to perceive is thus subject to first amendment checks. ${ }^{145}$

138. See, e.g., Whitney v. California, 274 U.S. 357, 372-80 (1927) (Brandeis, J., concurring); Abrams v. United States, 250 U.S. 616, 624-31 (1919) (Holmes, J., dissenting).

139. Cf. Banzhaf v. FCC, 405 F.2d 1082, 1102 (1968) ("A primary First Amendment policy has been to foster the widest possible debate and dissemination of information on matters of public importance."), cert. denied, 396 U.S. 842 (1969).

140. 250 U.S. 616 (1919).

141. Id. at 630 (Holmes, J., dissenting). But see L. Tribe, supra note 17, at 577, suggesting that free trade in ideas may not in fact generate truth, and that the right to differ about what is truth may be subtly endangered by a theory that perceives the attainment of truth-and therefore the banishment of error-as the sole purpose of communication. See also A. Meiklejohn, supra note 38, at 88 ("[T] he winning of the truth is important. . . . But that is not our deepest need.").

142. J.S. Mill, supra note 136. Mill emphasized in this context that "[t]o discover to the world something which deeply concerns it . . . is as important a service as a human being can render to his fellow creatures." Id. at 33.

143. See First Nat'l Bank v. Bellotti, 435 U.S. 765, 783 (1978). But see Gellhorn, The Right to Know: First Amendment Overbreadth?, 1976 Wash. U.L.Q. 25, 27-28.

144. This section of the Note draws on the philosophical theories of Ernst Cassirer (1874-1975). See generally E. Cassirer, Essay on Man (1953) [hereinafter cited as E. Cassirer, Essay]; E. Cassirer, The Phenomenology of Knowledge (1957) [hereinafter cited as E. Cassirer, Phenomenology]; The Philosophy of Ernst Cassirer (P. Schilpp ed. 1949).

145. See Neuborne, A Rationale for Protecting and Regulating Commercial Speech, 46 Brooklyn L. Rev. 437, 448-49 n.28 (1980) (but querying whether a sufficient link exists between 
The rationale for such a value can be found through an examination of the process of the individual's construction of his world-picture. The individual begins by breaking up the continuous flow of sensory phenomena into fixed, discrete perceptual units. These units serve as centers of orientation, as bases for the structuring and determination of this internal picture of the external world. ${ }^{148}$ As the process continues, its result is an ever-sharper description and differentiation of that perceptual universe. ${ }^{147}$ The individual is thus constantly building up a subjective picture of the external world, "controlled by perceptions of facts and their relationships to one another." 148 Goethe, describing this, wrote:

Truly the mental fleece

Resembles a weaver's masterpiece,

Where a thousand threads one treadle throws,

Where fly the shuttles hither and thither

Unseen the threads are knit together,

And an infinite combination grows. ${ }^{149}$

Each perceived element of the external world is built up in the individual mind as a phenomenal object; ${ }^{150}$ by means of this personal symbolic universe, the individual can translate and synthesize his own experience. ${ }^{151}$ Information about the external world constitutes the building blocks for this internal world-picture; ideas constitute the structural framework linking these blocks, by providing relations between facts. Images with pure emotional content, by contrast, neither informational nor ideological, play no part in this scheme. The process is at the core of what it means to be a perceiving, thinking being. Ensuring the ability of the individual to partake of the process is, it is here proposed, an underlying value beneath the first amendment.

commercial information and this process). Though commentators have in the past discussed growth through the reception of speech, they have rarely focused precisely on the process described here. See J. Dewey, Democracy and Education 6 (1916) ("[A]ll communication . . is education. To be a recipient of a communication is to have an enlarged and changed experience. One shares in what another has thought and felt and in so far, meagerly or amply, has his own attitude modified."); Redish, supra note 42, at 438-39 ("[T]he mind develops when used, and communication which stimulates the reader or listener to think, reason, know, consider, appreciate, or imagine constitutes an exercise of this ability unique to man, and hence stimulates development of it.").

146. Hamburg, Cassirer's Conception of Philosophy, in The Philosophy of Ernst Cassirer, supra note 144 , at $73,97$.

147. E. Cassirer, Phenomenology, supra note 144 , at $114-15$. In psychological terms, acquiring knowledge from the outside world means a change in cognitive structure, involving new connections or separations, differentiations or structuralizations of psychological areas within the life space of the individual. See K. Lewin, Field Theory in Social Science 69-75 (1951).

148. J. Dewey, supra note 145 , at 120 (defining the mind as purposive activity so controlled). 149. Quoted in Hartman, Cassirer's Philosophy of Symbolic Forms, in The Philosophy of Ernst Cassirer, supra note 144, at 289, 304-05.

150. See E. Cassirer, Phenomenology, supra note 145 at 4-5 (describing Kantian theory).

151. E. Cassirer, Essay, supra note 144, at 278. See also Aristotle, De Anima, in The Basic Works of Aristotle 590 (R. McKeon ed. 1941) ("Once the mind has become each set of its possible objects, ... . its condition is still one of potentiality, but in a different sense from the potentiality which preceded the acquisition of knowledge by learning or discovery: the mind is then able to think by itself." (emphasis in original)). 
Case support for the value is scant, but does reflect judicial willingness to protect the individual's ability to grow through learning. First hints may be found in Meyer v. Nebraska, ${ }^{152}$ in which the Court struck down a 1919 state statute banning the teaching of any modern language other than English below the ninth grade. ${ }^{153}$ The Court emphasized the "supreme importance" of the acquisition of knowledge, ${ }^{154}$ and suggested that the opportunities of pupils so to acquire knowledge could not be interfered with. ${ }^{155}$ These hints were developed in further Supreme Court statements dealing with education, including the opinion of the Court in Pierce $v$. Society of Sisters ${ }^{158}$ and its recent opinions in Plyer v. Doe ${ }^{157}$ and Board of Education, Island Trees Union Free School District v. Pico. ${ }^{158}$

\section{262 U.S. 390 (1923).}

The meaning of Meyer has been the occasion of a great deal of controversy. The Court in Griswold v. Connecticut, 381 U.S. 479 (1965), read Meyer and Pierce v. Society of Sisters, 268 U.S. 510 (1925), to mean that "the State may not, consistently with the spirit of the First Amendment, contract the spectrum of available knowledge," 381 U.S. at 482, and the case has been cited in specific support of the first amendment rights of students, see Tinker v. Des Moines School Dist., 393 U.S. 503, 506 (1969). In addition, however, the case has been characterized as standing for economic due process principles and concerned essentially with the right to contract, see Griswold v. Connecticut, 381 U.S. 479, 515-16 \& n.7 (1965) (Black, J., dissenting); as reflecting a general privacy right, see Carey v. Population Servs. Int'l, 431 U.S. 678, 685 (1977); Roe v. Wade, 410 U.S. 113, 152 (1973); and as basically concerned with family life and the parentchild relationship, see Quillion v. Walcott, 434 U.S. 246, 255 (1978).

The Meyer Court refers in its discussion to three of these rights: "the calling of modern language teachers," "the power of parents to control the education of their own," and "the opportunities of pupils to acquire knowledge." 262 U.S. at 401.

153. The Court rested its holding on the liberty protected by the fourteenth amendment. Courts of the 1920's, however, uniformly cited "liberty" and "due process" as the grounds for striking down state statutes violating a bill of rights guarantee. See, e.g., Fiske v. Kansas, 274 U.S. 380 (1927) (striking down a state statute restricting speech on the ground that the restriction infringed "the liberty of the defendant in violation of the due process clause of the Fourteenth Amendment," id. at 387).

154. 262 U.S. at 400.

155. Id. at 401 ("the opportunities of pupils to acquire knowledge"); id. at 399 ("the right of the individual ... to acquire useful knowledge").

156. 268 U.S. 510 (1925). The Court there struck down a state statute requiring that all school-age children be sent to public schools, emphasizing the inability of the state to "standardize" its children through mandating public education, and the importance of parental control over education. Id. at 535. See also the various opinions in Wisconsin v. Yoder, 406 U.S. 205 (1972). The Court here recognized a free exercise interest of Amish parents exempting them and their children from a state statute requiring school attendance until age 16. Justice Douglas, dissenting, appeared to recognize in the Amish child an affirmative right to a public education that his parents' wishes could not override. Id. at 245. He appears, however, to have been motivated not so much by first amendment concerns as by a more general "right of students to be masters of their own destiny," id., as well as by a fear that keeping Amish children out of school because of their parents' religious views might constitute an establishment of religion, id. at 242 . Justice White, while concurring in the exemption from school attendance, placed great emphasis on the state need to "nurture and develop the human potential of its children . . . to expand their knowledge, broaden their sensibilities, kindle their imagination, foster a spirit of free inquiry, and increase their human understanding and tolerance." Id. at 239 (White, J., concurring).

157. 50 U.S.L.W. 4650,4655 (U.S. June 15, 1982).

158. 50 U.S.L.W. 4831 (U.S. June 24, 1982). While the Court has explicitly rejected the idea that education-or at least education beyond a basic minimum-is a "fundamental right" for equal protection purposes, San Antonio School Dist. v. Rodriguez, 411 U.S. 1 (1973), in Plyer it 
The value of development through perception focuses, of course, on the listener interest; it thus incorporates the scope of protection associated with that interest. The value is necessary because the discovery value, focusing on the process interest, may often provide insufficient protection in those cases in which no speaker interest can be asserted and the political self-government value is not implicated. First, the emphasis of the discovery value on a broad marketplace of ideas places a premium on public speech addressed to a wide and general audience. ${ }^{159}$ Speech may, however, advance individual growth even where it is not addressed to the world at large. Where the speaker interest is unavailable, ${ }^{160}$ the discovery value may provide inadequate protection to private speech.

Second, the discovery value, focusing as it often does on a metaphysical marketplace of ideas, may tend to slight the flesh-and-blood actors in the communications process. The discovery value may be insufficient to protect listeners in cases where a listener's contribution to the communications marketplace of ideas is seen to be outweighed by the burden on the process of including him. One example might be found in Bates v. State Bar, ${ }^{101}$ where two of the dissenting opinions argued that the listener claim to receive attorney advertising should be denied because of the burden on the communications process presented by the problem of policing attorney advertising. ${ }^{162}$

appeared to treat public education as somehow quasi-fundamental, playing a special role in equal protection jurisprudence. See 50 U.S.L.W. at 4655.

The Court's decision in Rodriguez is not inconsistent with the theory proposed here. A first amendment principle that the government not unduly interfere with the individual's development through perception and integration of new information does not necessarily imply an affirmative obligation on the part of the government to contribute to that process through the medium of public education.

159. For example, in Abrams v. United States, 250 U.S. 616 (1919), in which Justice Holmes so eloquently emphasized the value of "free trade in ideas," see supra text accompanying notes $140-41$, the defendants had printed up and distributed some 5000 circulars promoting the cause of solidarity with the Russian Revolution. Id. at 618-20.

There was thus no difficulty asserting a process interest in Red Lion, which involved a true public marketplace of ideas, see supra notes 107-10 and accompanying text. Such a public marketplace has been found in almost every case in which the Court has asserted a process interest. See, e.g., First Nat'l Bank v. Bellotti, 435 U.S. 765 (1978); Kleindienst v. Mandel, 408 U.S. 753 (1972), and supra text accompanying note 113. In Procunier v. Martinez, 416 U.S. 396 (1974), where such a public marketplace was not found, the Court's claim that it was protecting "a particular means of communication [prisoners' letterwriting] in which the interests of both parties are inextricably meshed," id. at 409 , does not ring true-the rest of the paragraph in which that statement is found suggests that the Court was in fact attempting to protect listener interests or non-first amendment privacy interests without saying so.

160. See, e.g., Procunier v. Martinez, 416 U.S. 396 (1974) (speaker an imprisoned felon); Kleindienst v. Mandel, 408 U.S. 753 (1972) (speaker a nonresident alien); Lamont v. Postmaster General, 381 U.S. 301 (1965) (same); see also Stanley v. Georgia, 394 U.S. 557 (1969) (obscene speech).

A prime example of speech where the speaker interest is unavailable is commercial speech, sec infra notes $168-70$ and accompanying text.

161. 433 U.S. 350 (1977).

162. Id. at 387-88 (Burger, C.J., dissenting); id. at 395-97 (Powell, J., dissenting). 
Analysis based on the discovery value may emphasize the latter factor to the detriment of the former. In that manner, the right to receive may not be granted proper protection absent a first amendment value directly tied to the listener interest. ${ }^{163}$

The development-through-perception value, like other first amendment values, does not establish any new constitutional rights independent of freedom of expression; rather, it is part of an attempt to answer the question of why expression is accorded special protection under the first amendment. ${ }^{164}$ Each value supplies a partial answer to that question by describing a process, uniquely linked with speech, that is basic to the development of the individual or the preservation of a free society. ${ }^{165}$ Thus, speech is the express medium of that process of self-realization through the sharing of information and ideas that is protected by the self-expression value; that process of discovery of truth through the encounter of opposing ideas that is protected by the discovery value; that process of articulation, dissemination, and competition of information and ideas relevant to political self-government that is protected by the self-government value; and that process of taking in new information and ideas and integrating them into the individual's world-picture that is protected by the development-through-perception value. Speech is uniquely suited to all of these processes; other forms of activity may serve the same goals, but they do so incidentally and occasionally rather than by their nature. ${ }^{166}$ Thus, all of these processes are based on values that underlie the constitutional guarantee of freedom of speech.

\section{Values Underlying and Interests Furthered by Protection of COMMERCIAL SPEECH}

For speech to be within the first amendment preserve, it must advance one or more of the four underlying first amendment values. Since commercial speech does in fact promote three of the four values, it must be granted some protection. ${ }^{167}$ The scope of that protection, however, will be determined through an analysis of the interests advanced by commercial speech.

163. See also the discussion of the marginal listener, supra note 115 and accompanying text.

164. Cf. Jackson \& Jeffries, supra note 9 , at 13 (Values should "capture in reliable summary the dominant conceptions of the meaning of freedom of speech.").

165. The unique link with speech is crucial; thus while motorcycle riding may in fact contribute to the individual growth of some persons, it does not deserve first amendment protection on that ground. See Bork, supra note 79 , at 127 . But see Redish, supra note 42 , at 444 ("[A]ttempts by the courts to choose a vehicle for rational development are an unwarranted restriction of individual freedom.").

166. But see J. Dewey, supra note 145, at 321 (emphasis in original):

[T] here is no such thing as genuine knowledge and fruitful understanding, except as the of fspring of doing. The analysis and rearrangement of facts which is indispensable to the growth of knowledge and power of explanation and right classification cannot be attained purely mentally-just inside the head. Men have to do something to the things when they wish to find out something . . . .

See also id. at 172.

167. Rationales for protecting commercial speech have been advanced that, if followed, lead to protection on grounds other than the values identified in this Note, but none seems adequate to sustain first amendment protection for commercial speech. Most prominently, the Court has advanced economic efficiency and economic self-interest rationales for protection of commercial 


\section{A. Values Advanced by Commercial Speech}

Commercial speech advances the self-government, discovery, and development-through-perception values. It does not advance the self-expression value, because the speech that advances that value is speech motivated by the need of people "to express their opinions on matters vital to them if life is to be worth living," 168 speech that advances "the autonomous control over the development and expression of one's intellect, interests, tastes and personality." ${ }^{169}$ Commercial speech does not reflect that subjective need.170 The hawking of wares constitutes no expression of the individual personality.

speech, see supra text accompanying notes $35-41$. The economic efficiency theme, first enunciated in Virginia Board, was addressed most recently in Central Hudson Gas \& Elec. Co. v. Public Serv. Comm'n, 447 U.S. 557, 561-62 (1980). It has been adopted by some of the lower courts. See, e.g., Illinois Ass'n of Realtors v. Village of Bellwood, 516 F. Supp. 1067, 1069 (N.D. 1ll. 1981). The economic self-interest theme has been repeated as well by the Court, though in recent cases it has been emphasized more by the minority. See Friedman v. Rogers, 440 U.S. 1, 22-23 (1979) (Blackmun, J., dissenting); Ohralik v. Ohio State Bar Ass'n, 436 U.S. 447, 473-74 (1978) (Marshall, J., concurring). Consolidated Edison Co. v. Public Serv. Comm'n, 47 N.Y.2d 94, 390 N.E.2d 749, 417 N.Y.S.2d 30 (1979), the state level decision in Central Hudson, provides a useful illustration of the scope of protection under this approach. That court found that since electrical utilities operate in a noncompetitive market, and consumers have no choice regarding the source of their electric power, electrical utility advertising does not increase the ability of the consumer to make advantageous economic decisions. Thus, the court reasoned, the speech should not be protected. Id. at 110-11, 390 N.E.2d at 757, 417 N.Y.S.2d at 38-39. The Supreme Court endorsed the general approach but rejected the conclusion, finding that the consumer, in several markets, needs information to decide whether to buy electricity on the one hand, or fuel oil or natural gas on the other. Central Hudson, 447 U.S. at 567 . The objections to both the economic interest and the economic efficiency approaches, set out supra in text accompanying notes 38-41, are strong.

Professor Redish has advanced "personal self-government" and growth-through-decisionmaking arguments for protection of commercial speech. In the first, he argues that the first amendment demands that the consumer be presented with as much information as possible concerning the relative merits of competing products so that he can "achieve the maximum degree of material satisfaction permitted by his resources." Redish, supra note 42 , at 433 . He argues that the same forces that lead us to protect speech directed towards political decisionmaking should lead us to protect speech directed at private decisionmaking. After all, "much political activity is directed to the betterment of the individual's material welfare." The "same basic goal""improving [the] level of material satisfaction" of the individual-is implicated in both cases. 1d. at 443. This reasoning, though, misses the essential point of political freedom. Political freedom is not an incidental means toward the goal of individual material satisfaction; it is an end in itself. It is indispensable to the legitimacy of the individual's submission to the rule of the majority, and its first goal is self-government, not good government. The good life, without more, is not a first amendment value.

In Professor Redish's growth-through-decisionmaking argument, he contends that involvement in decisionmaking advances the rational development of the individual, and that the government cannot interfere with this vehicle for rational development. But rational development, without more, proves too much to be a first amendment value, and is insufficiently connected with speech. Many modes of activity may advance rational development, and yet are surely outside the ambit of the first amendment.

Finally, arguments for protection have been made that rest on the difficulty of line drawing, see supra note 42 , or that reject entirely the approach of affording first amendment protection only if it can be grounded on some "value," see supra note 79.

168. Z. Chafee, supra note 85 , at 33 .

169. Roe v. Wade, 410 U.S. 113, 211 (1973) (Douglas, J., concurring) (emphasis omitted).

170. See T. Emerson, The System, supra note 128, at 311; Baker, supra note 85, at 3; Jackson \& Jeffries, supra note 9, at 14; cf. First Nat'I Bank v. Bellotti, 435 U.S. 765, 804-05 (1978) (White, J., dissenting) (corporate political speech does not advance the expression value and should therefore be less protected than other political speech). But see Redish, supra note 42, at 446-47; The Supreme Court, 1979 Term, supra note 6, at 165. 
Protection of commercial speech does, however, advance the political self-government value. On the one hand, it does not implicate the speaker interests associated with that value, because the advertiser is not seeking to contribute to political discussion: were he trying to do so, then his speech could not properly be termed commercial. ${ }^{171}$ On the other hand, a different standard applies when the process and listener interests associated with the value are considered. The standard is no longer the subjective one of whether the speaker wishes to contribute to political discussion. Rather, it is an objective one: whether the speech does in fact contribute to the formation of political opinions among its hearers. Even though commercial speech does not constitute a direct contribution to the interchange of political ideas, it satisfies this standard because it transmits information and values that contribute to the public's formation of political opinions. ${ }^{172}$

For many of the same reasons, commercial speech also advances the discovery value. Since absolute truth is unattainable in any area of thought, speech that conveys information in any area will advance the search for truth. Informational speech, therefore, deserves discovery-value protection even when the information conveyed appears mundane or unimportant. ${ }^{173} \mathrm{Com}-$ mercial speech satisfies the test, ${ }^{174}$ since it transmits information from advertisers to consumers. ${ }^{175}$ Because the test is an objective one, subjective factors such as the speaker's commercial motivation are irrelevant. ${ }^{176}$

171. See Virginia State Bd. of Pharmacy v. Virginia Citizens Consumer Council, Inc., 425 U.S. 748, 761-62 (1976); see also supra note 2. Compare Central Hudson Gas \& Elec. Corp. v. Public Serv. Comm'n, 447 U.S. 557, 562 n.5 (1980), with id. at 580-81 (Stevens, J., concurring).

172. See Virginia State Bd. of Pharmacy v. Virginia Citizens Consumer Council, Inc., 425 U.S. 748, 765; id. at 780 n.8 (Stewart, J., concurring); In re Bates, 113 Ariz. 394, 402-03, 555 P.2d 640, 648-49 (1976) (Holohan, J., dissenting), rev'd, 433 U.S. 350 (1977).

This indirect link allows commercial speech to advance the self-government value without reaching the level of "political speech." Thus Jackson and Jeffries are overly limiting when they conclude that expression not "essential to self-government" is "irrelevan[t] . . to the political speech principle." Jackson \& Jeffries, supra note 9, at 15.

173. Commercial speech is sometimes dismissed as not relating to important areas of knowledge. A distinction is drawn between "true" rational knowledge, touching reality in an ultimate, intellectual fashion, on the one hand, and knowledge dealing with everyday affairs, on the other; "true" knowledge is purely theoretical and must not be debased by application to real behavior. The concept is first found in classical philosophy and was reinforced in medieval thought: "[K]nowledge is high and worthy in the degree in which it deals with ideal symbols instead of with the concrete. ... Experience ha[s] to do with mundane, practical and secular affairs, practically necessary indeed, but of little import in comparison with supernatural objects of knowledge." $\mathrm{J}$. Dewey, supra note 145 , at 310 . The class basis of such a dichotomy is plain, id. at 389 , and the dichotomy itself is pernicious and untenable. Id. at 391. Establishment of such a hierarchy of values is unacceptable; all studies and all knowledge, insofar as they contribute to experience, have intrinsic and incomparable worth. Id. at 281.

174. Of course, not all advertising does transmit information. A great deal of advertising emphasizes persuasional and noninformational techniques to the exclusion of useful facts about the product. Most advertising, though, presents both information and persuasion, and a line cannot reasonably be drawn between the two types. See Redish, supra note 42 , at 433 .

175. But see Banzhaf v. FCC, 405 F.2d 1082, 1102 (D.C. Cir. 1968) (even though cigarette advertising "implicitly states a position on a matter of public controversy," it "present[s] no information or arguments in favor of smoking which might contribute to the public debate."), cert. denied, 396 U.S. 842 (1969).

176. See Bigelow v. Virginia, 421 U.S. 809,826 (1975). 
Since commercial speech conveys information, it advances the development-through-perception value as well. Here, too, all speech that conveys information advances the value. It is not a legitimate objection that commercial information contributes to the development of the individual's worldpicture in an unimportant area, or that commercial information does not sufficiently contribute at all. The first objection is based upon a misunderstanding of the nature of the value; its goal is the continual differentiation and development of the individual's perception of the external world, not the encouragement of his knowledge and talents in some particular area. The second objection implies that this cognitive development is a first amendment goal only when "important" strides are made by the individual, but that seems untenable-many little strides make one great one, and the government cannot choose for the individual the information it thinks will benefit him most. Since commercial speech promotes the perceptional development value, it advances listener interests. Again the proper criterion is one of content; the commercial motivation behind the speech cannot remove its value. ${ }^{177}$

\section{B. Scope of First Amendment Protection of Commercial Speech}

Because commercial speech advances first amendment values, it deserves first amendment protection. In contrast to other types of speech, however, it implicates only process and listener interests; protecting commercial speech does not foster any speaker interests that the first amendment recognizes. ${ }^{178}$ This puts it in a unique position, since the protection of no other general class of speech advances first amendment values without advancing speaker interests. ${ }^{179}$

One consequence of that distinction is that balancing tests, where employed by a court considering restrictions on commercial speech, are skewed toward suppression. ${ }^{180}$ Since commercial speech advances only listener and process interests, a court applying a balancing test to determine the validity of a restriction on commercial speech does not weigh the expressional interests of a speaker against the interests of society in regulating speech; rather, it weighs the interest of the public in hearing the speech against the interest of that very same public in not hearing it. Under these circumstances, balancing a well-

177. An analogy can instructively be drawn to the Court's treatment of sexually explicit speech in Winters v. New York, 333 U.S. 507, 510 (1948). The Court wrote: "We do not accede to appellee's suggestion that the constitutional protection for a free press applies only to the exposition of ideas. The line between the informing and the entertaining is too elusive for the protection of that basic right. . . . What is one man's amusement, teaches another's doctrine."

178. Of course, the interests of commercial speakers in making money will always be advanced by protecting their speech, but mere economic interests should not be protected by the first amendment. See Virginia State Bd. of Pharmacy v. Virginia Citizens Consumer Council, Inc., 425 U.S. 748, 783-88 (Rehnquist, J., dissenting); A. Meiklejohn, supra note 38; supra text accompanying notes $38-41$.

179. But see supra notes 90-101 and accompanying text for particular examples of speech satisfying this test; see also the discussion of Young v. American Mini Theatres, Inc., 427 U.S. 50 (1976), supra note 105 .

180. See Comment, supra note 28 , at $808-11$. 
defined harm against an amorphous benefit, courts can rarely be expected to strike down the restriction. ${ }^{181}$

More important, however, are the consequences of the absence of speaker interests with respect to the legitimacy of specific types of regulation. Restrictions on particular speakers or modes of speech are legitimate so long as they do not interfere with reception of the information and ideas in question from other speakers or via other modes of speech. However, suppression of the content of speech, as in Central Hudson, is not permissible except pursuant to a strict standard of scrutiny.

1. Regulation not Interfering with Reception of the Information or Ideas. A restriction on particular commercial speech will always be valid where the restriction does not interfere with the transmittal of the information in question to the public, because of the existence of other speakers ${ }^{182}$ or the availability of alternative means. ${ }^{183}$ This constitutes a marked departure from analysis in other first amendment areas in which the Supreme Court has repeatedly held that speech cannot be suppressed simply because the substance of the speech has been voiced by others, or because the speaker will be able to convey his message by some other means. ${ }^{184}$ This is because speaker interests are paramount in traditional first amendment analysis. In commercial speech analysis, by contrast, only listener and process interests need be protected. Thus, where a restriction of commercial speech is at issue, the reviewing court must determine whether the restriction will in fact cut back on the amount of information or ideas getting through to the public. ${ }^{185}$

181. See generally Goodale, Legal Pitfalls in the Right to Know, 1976 Wash. U.L.Q. 29; Comment, supra note 28 , at 808-10 ("first amendment protection for purely commercial speech may be illusory").

182. Justice White, dissenting in First Nat'l Bank v. Bellotti, 435 U.S. 765 (1978), suggested that a state might be able to regulate corporate political speech, on the ground that "it is unlikely that any significant communication would be lost by such a prohibition," but not corporate commercial speech, since "[i]n the absence of advertising . . . the ability of consumers to obtain information relating to products manufactured by corporations would be significantly impeded," id. at 807-08.

183. See Village of Hoffman Estates v. Flipside, Hoffman Estates, Inc., $102 \mathrm{~S}$. Ct. 1186, 1192 (1982) ("We doubt that the village's restriction on the manner of marketing appreciably limits Flipside's communication of information. . . ."). But see Kleindienst v. Mandel, 408 U.S. 753,765 (1972) (existence of alternative means to receive the restricted speech did not "extinguish ... altogether any constitutional interest . . . in this particular form of access"); see also Board of Educ., Island Trees Union Free School Dist. v. Pico, 50 U.S.L.W. 4831 (U.S. June 24, 1982). In both Kleindienst and Island Trees, the Court sought to protect only listener interests.

184. Schneider v. State, 308 U.S. 147, 163 (1939); see L. Tribe, supra note 17, at 603.

185. The Virginia Board Court implicitly made such a determination when it rejected Justice Rehnquist's argument that no listener interests protected by the first amendment were implicated since consumers could in theory collect and publish.the drug price information themselves. Virginia State Bd. of Pharmacy v. Virginia Citizens Consumer Council, Inc., 425 U.S. 748, 757 n.15 (1976); see supra note 102. That alternative, while acceptable in theory, was likely to have been inadequate in practice. The Linmark Court similarly examined alternative means of communicating that a house was for sale and found them "far from satisfactory." Linmark Assocs. v. Township of Willingboro, 431 U.S. 85, 93 (1977). The Friedman Court argued that even though trade names were to be banned, "the factual information associated with trade names may be communicated freely and explicitly to the public" and that the regulation was on that ground among others legitimate. Friedman v. Rogers, 440 U.S. 1, $16(1979)$. On the facts of Friedman, however, the argument seems specious; the restriction, after all, was designed to put the speaker out of business. See id. at 23 (Blackmun, J., dissenting). 
This analysis is helpful in scrutinizing congressional regulation of cigarette advertising. ${ }^{186}$ The ban on cigarette advertising over the electronic media ${ }^{187}$ is unobjectionable to the degree that the same content is conveyed to the public through print media advertising. The requirement of a conspicuous Surgeon General's warning, ${ }^{188}$ or any other mandated disclosure, ${ }^{180}$ similarly presents no first amendment issue since it in no way lessens the amount of information communicated to the public. ${ }^{190}$

2. Central Hudson-Type Regulation. In traditional first amendment analysis, the suppression of speech because of its topic or point of view is presumptively invalid. Strict scrutiny is necessary in such cases. ${ }^{101}$ Yet in Central Hudson the Court implicitly recognized the validity of restrictions on speech that not only regulate on the basis of content, but were promulgated for the express purpose of influencing public behavior by preventing a specific point of view from being communicated to the public. Such regulation can be justified only if speech advancing listener and process interests exclusively is more susceptible to content and viewpoint regulation than is speech that advances speaker interests as well. In order to make that determination, it is necessary to consider the bases for the traditional proscription of content regulation.

Content-based regulations of speech have commonly been reviewed by means of equal protection analysis. ${ }^{192}$ Such restrictions implicate equal protection principles because they establish classifications of speakers based on the content of their speech. ${ }^{193}$ These classifications must be subjected to careful scrutiny because of the fundamental nature of the first amendment

186. 15 U.S.C. $\S \S 1331-1340$ (1976).

187. 15 U.S.C. $\S 1335$ (1976).

188. 15 U.S.C. $\$ 1333(1976)$.

189. See, e.g., Warner-Lambert Co. v. FTC, 562 F.2d 749, 756-64 (D.C. Cir. 1977), cert. denied, 435 U.S. 950 (1978); Fur Products Labeling Act, $\S 4(2), 15$ U.S.C. $\$ 69 \mathrm{~b}(2)$ (1976).

190. The mandatory warning is thus a prime example of a regulation that would raise serious freedom-of-expression problems if speaker interests could be asserted, but raises no such problems precisely because no speaker interests protected by the first amendment can be found.

Of course, requiring an unreasonably large warning that eliminated space otherwise used to convey commercial information not elsewhere available would implicate the first amendment.

191. Metromedia, Inc. v. City of San Diego, 453 U.S. 490, 514-15 (1981); Consolidated Edison v. Public Serv. Comm'n, 447 U.S. 530, 537-38 (1980); Carey v. Brown, 447 U.S. 455, 462-63 (1980).

192. Carey v. Brown, 447 U.S. 455 (1980); Young v. American Mini Theatres, 427 U.S. 50 (1976); Police Dep't v. Mosley, 408 U.S. 92 (1972); Neimotko v. Maryland, 340 U.S. 268, 284 (1951) (Frankfurter, J., concurring).

Restrictions on speech are often attacked on equal protection and first amendment grounds simultaneously. See Widmar v. Vincent, 102 S. Ct. 269 (1981); FCC v. Nat'l Citizens Comm. for Broadcasting, 436 U.S. 775, 801 \& n.19 (1978); see also California v. LaRue, 409 U.S. 109, 138 (1972) (Marshall, J., dissenting); Police Dep't v. Mosley, 408 U.S. 92, 95-96 (1972).

193. See, e.g., Police Dep't v. Mosley, 408 U.S. 92, 94-95 (1972).

The concept of "public forum" is often applied in this connection. The term is properly limited to situations in which free speech is made available to some speakers, and thus the classification leads to differential treatment. It excludes situations in which free speech is available to nobody, and as a result there exists no differential treatment and no equal protection problem. See Widmar v. Vincent, 102 S. Ct. 269, 273-74 (1981). Because free speech has traditionally been available in the streets and parks, these are often referred to as public forums. See, e.g., Carey v. Brown, 447 U.S. 455, 460 (1980); Police Dep't v. Mosley, 408 U.S. 92 (1972). The concept has often been misused. In United States Postal Serv. v. Council of Greenburgh Civic Ass'ns, 453 U.S. 114 (1981), the Court used a finding of no public forum as the basis for a holding that no 
rights implicated. ${ }^{194}$ However, equal protection analysis is not applicable where the speech in question does not advance speaker interests. Regulation of such speech does not set up a classification on which an equal protection analysis can be bottomed. There is no classification of speakers, since no speaker interests protected by the first amendment exist. There is no classification of listeners, since the nonspeaker interests protected by the self-government, discovery, and perceptional-development values each reflect benefits to the general public; particular segments of society are not disproportionately benefited by a particular speech content. ${ }^{195}$ Thus, equal protection analysis fails to establish a ground on which to proscribe Central Hudson-type regulation of commercial speech.

Central Hudson-type regulation, nonetheless, cannot stand. Contentbased regulation is traditionally subject to direct first amendment attack ${ }^{196}$ in two situations: those in which the government sets the agenda for public discussion, and those in which the government favors certain viewpoints over others. ${ }^{197}$ These barriers to government action arise directly out of the first amendment, and operate regardless of whether the censored speech advances speaker interests. ${ }^{198}$ There is nothing in the nature of the listener or process

first amendment analysis at all was necessary, beyond a bare finding of reasonableness. This was surely wrong, since the presence or absence of a public forum should not affect the need to apply the usual balancing-test analysis given "time, place, and manner" restrictions on speech. See id. at 2692 (Marshall, J., dissenting).

The term is also used to single out situations in which differential treatment of speakers is necessary to avoid disruption of the operation of governmental facilities. Consolidated Edison $v$. Public Serv. Comm'n, 447 U.S. 530, 538 (1980). These situations are described as ones where no "public forum" can be found, and extremely relaxed scrutiny is applied. See Jones v. North Carolina Prisoners' Labor Union, Inc., 433 U.S. 119 (1977); Greer v. Spock, 424 U.S. 828 (1976); Lehman v. City of Shaker Heights, 418 U.S. 298 (1974). On a theoretical basis, this is incorrect. Such a finding of necessity should be used as a basis for a holding that the strict scrutiny standard is satisfied, not as an excuse for not applying the standard at all. But cf. Kleindienst v. Mandel, 408 U.S. 753, 767-70 (1972) (Congress's plenary power to exclude aliens found to be a justification for applying only relaxed scrutiny of first amendment-based claims arising out of such an exclusion).

194. Carey v. Brown, 447 U.S. 455, 461-62 (1980). In Metromedia, Inc. v. City of San Diego, 453 U.S. 490 (1981), the Court applied the principle with a vengeance, invalidating an antibillboard ordinance in part because the ordinance contained exceptions for religious symbols, commemorative historical plaques, news, time and temperature signs, signs pertaining to an official governmental function, and temporary political campaign signs. These exceptions should properly be termed "frivolous," id. at 563 (Burger, C.J., dissenting).

195. This would not be the case under the Court's "economic self-interest" argument. Given such a value structure, "the poor, the sick, and particularly the aged" are indeed benefited disproportionately by certain classes of commercial speech, Virginia State Bd. of Pharmacy v. Virginia Citizens Consumer Council, Inc., 425 U.S. 748, 763 (1976), and an equal protection analysis could be undertaken.

196. Compare Carey v. Brown, 447 U.S. 455,459 n.2, 459-71 (1980) (equal protection analysis), with id. at 471 (Stewart, J., concurring) (first amendment analysis); Young v. American Mini Theatres, 427 U.S. 50, 63-73 (1976), with id. at 84 (Stewart, J., dissenting).

197. See Board of Educ., Island Trees Free School Dist. v. Pico, 50 U.S.L.W. 4831, 4836 (U.S. June 24, 1982); Consolidated Edison v. Public Serv. Comm'n, 447 U.S. 530, 537-38 (1980) (impermissible "to allow [the] government control over the search for political truth"); Cox v. Louisiana, 379 U.S. 536, 581 (1965) (Black, J., concurring) (viewpoint-biased regulation "censorship in a most odious form"); see also Metromedia, Inc. v. City of San Diego, 453 U.S. 490, 552 (1981) (Stevens, J., dissenting); Carey v. Brown, 447 U.S. 455, 481 (1980) (Rehnquist, J., dissenting).

198. See Central Hudson Gas \& Elec. Corp. v. Public Serv. Comm'n, 447 U.S. 557, 575-78 (Blackmun, J., concurring); Carey v. Population Servs. Int'l, 431 U.S. 678, 701 n.28 (1977) (such 
interests, or speech advancing only those interests, that indicates why government point-of-view favoritism should be permitted in that area more than in any other. ${ }^{199}$

Central Hudson-type regulation necessarily involves both viewpoint-biased regulation and regulation setting the agenda for public discussion. Central Hudson itself provides an example. There, a government agency issued an order banning advertising intended to promote electricity use. ${ }^{200}$ The regulation was one explicitly based on the point of view of the speaker; it banned speech intended to encourage energy use in order to promote a state policy of energy conservation. Linmark Associates v. Township of Willingboro ${ }^{201}$ provides another example. There, the town's ordinance banning "For Sale" signs in a racially changing community had two goals: one, to discriminate against speech tending to emphasize the black influx into the community; the other, to remove speech dealing with the changing nature of the community from the public agenda of discussion.

Regulation of commercial speech designed to influence behavior by depriving citizens of information, as in these cases, inevitably involves one or both of these proscribed restrictions. Thus, such regulation is impermissible unless it can meet a strict scrutiny standard; the absence of speaker interests in commercial speech does not mean that the government can violate basic principles of viewpoint- and public-agenda-neutrality.

\section{ConClusion}

An analysis of the value structure underlying the first amendment reveals that commercial speech significantly advances three of its four values and is therefore worthy of protection. Its position is unique because the speech does not advance any value implicating the interests of the speaker in the speech. This leads to a curtailment of the scope of protection in important ways, such as permitting the regulation of redundant speech. This unique position should not, on the other hand, make true, nonmisleading speech any more amenable than other types of protected speech to content-based restrictions designed to influence the behavior of the public by limiting the information available to it. Here, as elsewhere, such restrictions should be permitted only subject to a standard of strict scrutiny.

Jonathan Weinberg

restrictions "clearly directed not at any commercial aspect of the prohibited advertising but at the ideas conveyed and form of expression-the core of First Amendment values").

The Court in Central Hudson, 447 U.S. at $564 \mathrm{n} .6$, cited verifiability and durability as the two features of commercial speech that "permit regulation of its content." Yet both of these, while providing useful rationales for broad regulation of possibly misleading speech, provide no grounds on which point-of-view-biased or public-agenda-setting regulation of commercial speech can be justified. See id. at 574-79 (Blackmun, J., concurring).

199. Arguably, these proscriptions apply only to regulation of speech advancing the political self-government value. This distinction, however, is unlikely to be important in practical terms, since in most cases speech that the government seeks to suppress via content-based regulation implicates political matters or the free exercise clause or some other independently protected constitutional right.

200. Central Hudson Gas \& Elec. Corp. v. Public Serv. Comm'n, 447 U.S. 557, 559 (1980).

201. 431 U.S. 85 (1977); see supra notes $48-50$ and accompanying text. 